\title{
Exercising Musical Minds: Phrenology and Music Pedagogy in London circa 1830
}

\author{
DAVID TRIPPETT
}

\section{Skulls ANd Music}

Fully fifty-five years after the doctrine of phrenology first emerged in Franz Joseph Gall's Vienna in 1796, the Halle-based writer and singing teacher Gustav Nauenburg confessed publicly to having committed a "sin" by ignoring it. He was writing on music's behalf. As long as the study of art is cultivated in isolation, he proclaimed, it will remain "one-sided and deficient." ${ }^{1}$ Nauenberg's writings were long familiar to readers of the two major professional music journals published in Leipzig, the Neue Zeitschrift für Musik and the Allgemeine

\footnotetext{
A shorter version of this article was given at colloquia at Stanford, UC Davis, King's College London, and Bangor University. I am most grateful to colleagues and students for the invaluable feedback and discussions arising from those events.

${ }^{1 " S o}$ lange die Kunstwissenschaft isolirt cultivirt wurde, blieb sie einseitig und mangelhaft. ..." Gustav Nauenburg, "Die Phrenologie in ihrer Beziehung zur Tonkunst," Neue Zeitschrift für Musik 2 (10 January 1851): 13-16, here 13.
}

musikalische Zeitung, but this was his first and only statement about the pseudo-science of cranial contours. His claim of having studied phrenology "for some time and with the utmost impartiality" was a bold step in the arena of professional music journalism. ${ }^{2}$ It effectively announced his liberal views on the burning issue of the day: "Since it is now a fateful dictum to bring the arts and the sciences into a reciprocal relationship and interdependence, we can no longer ignore the irrefutable, fully proven results of phrenology, for they are crucially important for artistic judgment and education." 3 Hyperbole aside, such a personal endorsement

\footnotetext{
2"Ich habe mich seit längerer Zeit und möglichst unbefangen auch dem Studium dieser Wissenschaft hingegeben." Ibid.

3"Ist es nun eine folgenreiche Maxime, die Künste und Wissenschaften in eine gegenseitige Beziehung und Wechselwirkung $z u$ bringen, so dürfen wir auch die unabweisbaren, vollkommen erwiesenen Ergebnisse der Phrenologie nicht länger ignoriren, da sie für Kunstbeurtheilung und Kunsterziehung von der entscheidensten Wichtigkeit sind." Ibid.
} 
of phrenology's relevance to music is anomalous; given the idealist leanings of many writers on music, its publication made the author vulnerable to the standard accusations of determinism, atheism, and materialism.

Although no less an authority than Hector Berlioz had privately endorsed the materialist leanings of Gall's science, only a handful of articles of this kind exist in nineteenth-century professional music journals. ${ }^{4}$ London's Quarterly Musical Magazine and Review alerted its readers to the science as early as 1826 , as part of a drive to "introduce into our speculations as much of various science as we consistently can." 5 While the leading British music journal, Musical World, effectively declared itself against the enterprise by heading each issue with an idealist epigraph from Plato's Phaedo ("music is something viewless and incorporeal, and all-gracious and a God-like thing"l), numerous phrenological journals carried their own articles on music. ${ }^{6}$ Perhaps because of phrenology's eventual status as a disreputable pseudo-science, its historical importance to amateur music-making and musical discourse has been overlooked. Questions about why such articles stake a claim yet seemingly fail to persuade, why an interest in composer's skulls persisted, and why advocates of the science saw phrenological "knowledge" as an untapped resource for enhancing music education, all remain unasked.

Outside its historical dialogue with music, the story of phrenology has been told widely and often. ${ }^{7}$ Drawing on his observation of fam-

\footnotetext{
${ }^{4}$ Berlioz asserts, "my ideas are becoming firmer and more solid through studying the profound works of Locke, Cabanis, Gall and others; not that they teach me anything except technical details, because I generally find that I've gone further than they have and that they don't dare pursue the consequences of their principles for fear of public opinion"; Berlioz to Ferdinand Hiller, La Côte, 7 August 1832, in Selected Letters of Berlioz, ed. Hugh Macdonald, trans. Roger Nichols (London: Faber, 1995), 99-100.

${ }^{5}$ Anon., "The Great Symphonists," Quarterly Musical Magazine and Review 8 (1826): 213-35, here 215.

${ }^{6}$ This epigraph appears in Greek and English on the front page of each issue during 1839. It is taken from Phaedo, $\$ 36$, in which Socrates contrasts the divinity and immateriality of music with the mortality and materiality of its instruments.

${ }^{7}$ See Stephen Tomlinson, Head Masters: Phrenology, Secular Education, and Nineteenth-Century Social Thought
}

ily members, Gall first lectured on the topic in Vienna from 1796, employing Johann Spurzheim as his full-time assistant in brain dissection from 1804. Following their separation in 1813, it was Spurzheim's doctrine of individual and social perfectibility that eventually became popularized as phrenology. After Edinburgh, London became a center for phrenological discourse. Spurzheim popularized the subject when he began lecturing there in March 1814, settling in 1825 after his lectures had been banned in Paris, with one editor observing: "although the science arose in Germany, it was subsequently almost forgotten there." 8 A series of criticisms from leading academics only gave impetus to the formation of phrenological societies in Edinburgh (1820) and London (1823).9 In the capital, George Combe was a chief advocate and translated Spurzheim's principal writings into English, while James Deville was London's leading practitioner, producing a standard plaster bust of the brain in 1824 .

Broadly speaking, phrenological doctrine equated mind with brain and saw the brain not as a unitary organ but a composite of some thirty organs, each of which was responsible for a different intellectual or affective trait. Phrenology held that the brain's form could be ascertained by inspecting the contours and protrusions of the cranium, and that the functions of the several parts might be determined by comparing their size with the power of the corresponding mental faculties. "Every act of the will, every flight of imagination, every glow of affection, and every effort of the understanding in this life," Combe asserted in 1819, "is performed by means of an apparatus of organs

(Tuscaloosa: University of Alabama Press, 2005); Marc Renneville, Le Langage des cranes: histoire de la phrénologie (Paris: Sanofi-Synthélabo, 2000); Samuel Greenblatt, "Phrenology in the Science and Culture of the 19th Century," Neurosurgery 37 (1995): 790-805; Gerfried Kunz, Gustav von Struve und die Phrenologie in Deutschland (Mainz: Gutenberg-Universität Mainz, 1993); Roger Cooter, Phrenology in the British Isles (Metuchen, NJ: Scarecrow Press, 1989); and Cooter, The Cultural Meaning of Popular Science: Phrenology and the Organization of Consent in Nineteenth-Century Britain (Cambridge: Cambridge University Press, 1984).

${ }^{8}$ Editorial, "Phrenology in Germany," Phrenological Journal and Miscellany 4 (1826-27): 471.

${ }^{9}$ For an overview, see Stephen Tomlinson, Head Masters, $97 f f$. 
unknown to us through consciousness, but which are capable of demonstration by experiment and observation." 10 Such a theory was attractive to Comtean positivists because it offered a means of accessing the interiority and recessed creativity of mental life, whose invisible activity had hitherto frustrated a science based on empirical observation. ${ }^{11}$

Perhaps because Nauenburg's article aligned him with a contested doctrine with few roots in professional music journalism, it failed to spark discussion in the Neue Zeitschrift. No flicker of response followed. Yet there is nothing enigmatic about his challenge to music pedagogues. After summarizing the tenets of phrenology, he predicted a closer cooperation between pedagogues and phrenologists, seeking thereby to bring a theory of musical training in line with the putative gains of this "science":

Consider for a moment the normal educational path of our young composers. They master an instrument, study composition, instrumentation; in short, they become familiar with musical technique and then compose in all forms. The original organic predisposition is more or less left out of consideration. If by chance the young composer finds recognition in a particular kind of composition-he will tentatively continue with it; if not, the composer at some point tries a different artistic tack; sadly, many an aspiring composer reaches navigable water only after many failed and regrettable odysseys! Here the empirical science of phrenology can become a safe navigator in a great many cases. If the organs conditioned by awe, piety, by benevolence and music are large, for example, then compose religious music for the time being. If the organ for love of children is small, then avoid composing innocent children's songs; if the impulse towards combat and destruction are large, you would certainly succeed best in heroic, martial music. ${ }^{12}$

\footnotetext{
${ }^{10}$ George Combe, A System of Phrenology [1819], 3rd edn (Edinburgh: John Anderson, 1830), 9.

${ }^{11}$ Less persuasive, perhaps, were the far-fetched claims for the benefits of phrenological knowledge: from relieving all pain in childbirth to selecting the best partner for a happy marriage; see Combe, The Constitution of Man: Considered in Relation to External Objects, 11th edn. (Boston: Marsh, Capen, Lyon and Webb, 1841), 123, 155.

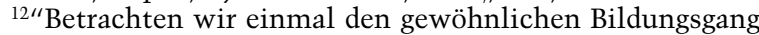
unserer jungen Componisten. Sie erlernen ein Instrument, studiren Compositionslehre, Instrumentirkunst, kurz sie
}

The aims of musically applied phrenology articulated so bluntly here can be seen refracted in London and Paris several decades earlier. The prospectus for the Phrenological Society in Paris asks, "How should that science fail to be of primary importance to a teacher, which should enable him to turn the studies of his pupils into the proper channel. . . . How many tears would not be spared to childhood!"13 A speculative article on symphonic composition in the Quarterly Musical Magazine and Review, cited above, inverts Nauenburg's compositional training into post facto diagnosis by mapping the musical characteristics of Haydn, Mozart, and Beethoven onto postulated readings of their crania by reference to their compositions. Drawing indirectly on the thirty-five areas of the brain listed in Combe's System of Phrenology, shown in plate 1 , the article exemplifies the transparently circular logic at the heart of phrenological discourse: ${ }^{14}$

We assign Beethoven very large tune, ideality and constructiveness, combativeness and destructiveness, large also, with concentrativeness, secretiveness, self esteem, firmness, and causality, somewhat more developed than in ordinary men-amativeness and veneration would be comparatively small. These organs will account for his invention and imagination, his

machen sich mit der musikalischen Technik vertraut und componiren nun in allen Compositions-Gattungen herum. Die ursprüngliche organische Anlage wird mehr oder weniger unberücksichtigt gelassen. Findet nun der junge Künstler zufällig in einer bestimmten CompositionsGattung Anerkennung, so wird vorläufig darinfortcomponirt; bleibt sie aus, so wird die Componisterei einmal auf einen anderen Kunstgebiete probirt; leider kommt manches hoffnungsreiche Kunsttalent erst nach vielen erfolglosen und vergeblichen Irrfahrten in sein eigentliches Fahrwasser! Hier kann in sehr vielen Fällen die phrenologische Erfahrungswissenschaft ein sicherer Pilot werden; sind z.B. die Organe der Ehrfurcht, Pietät, des Wohlwollens und die Musik bedingenden Organe großso componirt vorerst Kirchen- und religiöse Musik; ist das Organ der Kinderliebe klein-so schreibt ja keine harmlose Kinderlieder; sind Bekämpfungstrieb und Zerstörungstrieb groß-so wird Euch sicherlich heroische kriegerische Musik am besten gelingen." Nauenburg, "Die Phrenologie in ihrer Beziehung zur Tonkunst," Neue Zeitschrift für Musik 2 (1851): 16.

${ }^{13}$ Various, "Prospectus of the Phrenological Society of Paris," Phrenological Journal and Miscellany 7 (1831-32): 297.

${ }^{14}$ Combe, A System of Phrenology (1819; 2nd edn. 1825) front matter. Gall had listed twenty-seven areas of the brain; Spurzheim had listed thirty-three. 


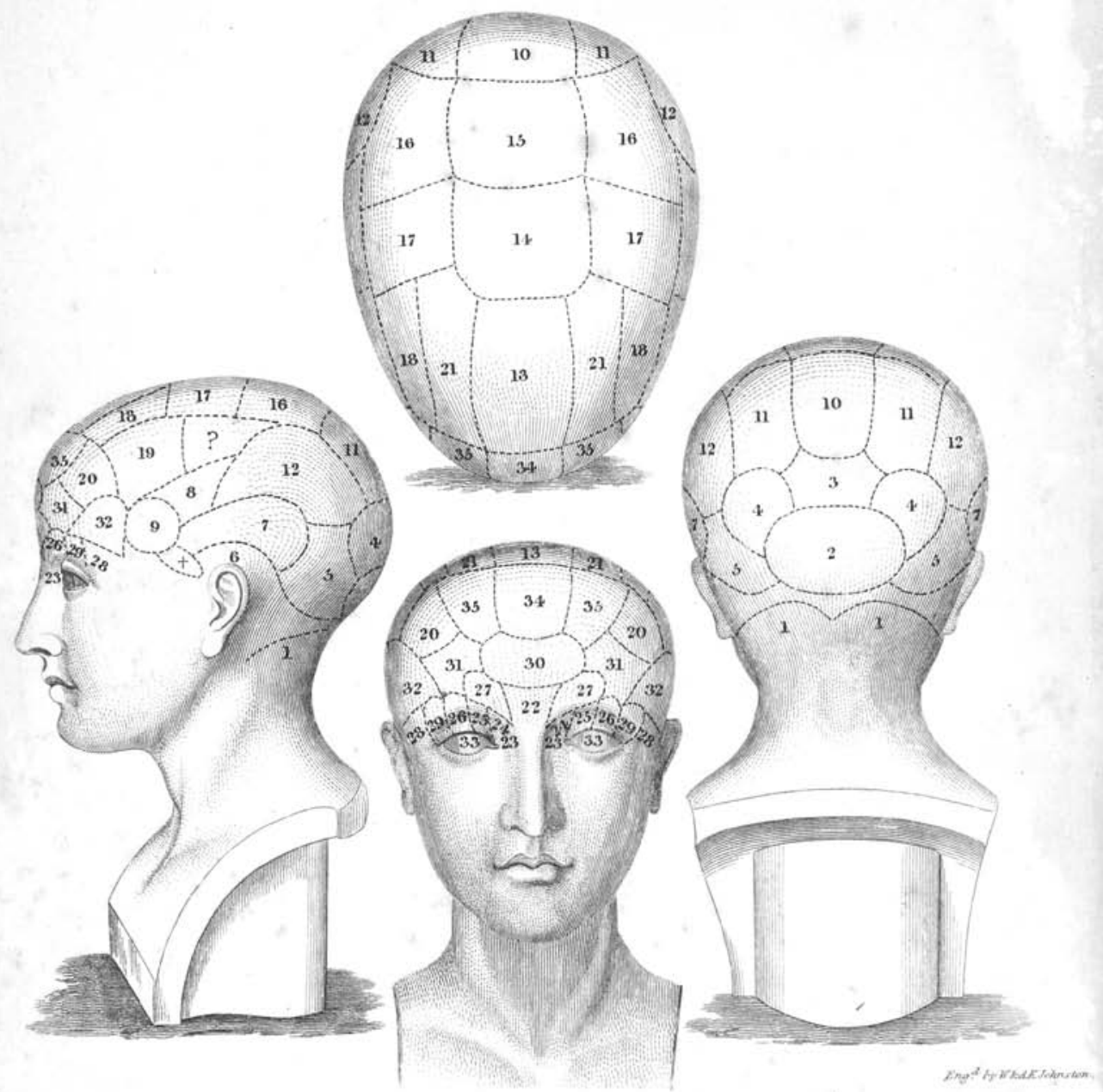

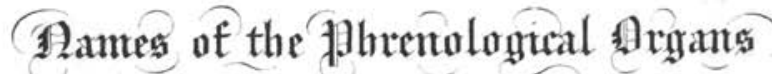

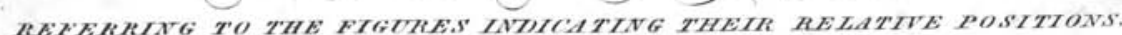

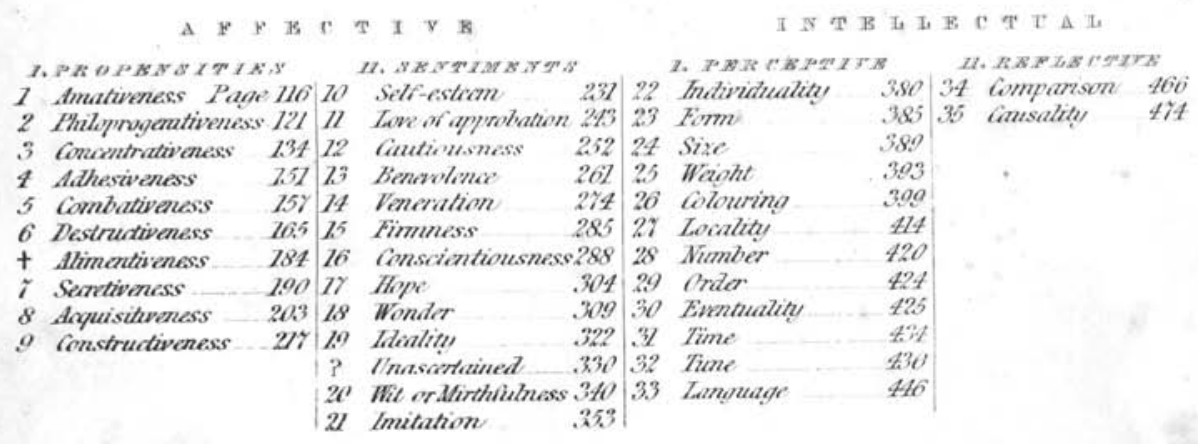

Plate 1: The frontispiece depicting the thirty-five areas of the brain listed in George Combe's System of Phrenology, 2nd edn. (1st edn. 1819; Edinburgh: J. Anderson, 1825). Credit: National Library of Scotland. 
vehemence and originality, his contempt of authority and determined adherence to his own rule of propriety, as well as the general absence of breathing tenderness that appertains to the other great musicians. ${ }^{15}$

The spirit of amateur curiosity in such speculation highlights what with hindsight appears to be a startling lack of professional rigor, and the musically trained editor cedes all authority by inviting practicing phrenologists "to give the public the benefit of [their] consideration of these points," later adding that since Beethoven is still alive, "our conjectures" may be put to the test. ${ }^{16}$

Phrenologists identified musical skill ostensibly with composition, specifically melodic composition. Yet the "faculty of Tune," situated just above the eyes by the temple, also became a byword for musical talent in all its manifestations. It was loosely defined by Combe as "the sense of melody and harmony arising from it." ${ }^{17}$ A London periodical defined it more closely as a sense of relative pitch: "perceiving the pitch of the several sounds of the octave, in relation to the key note of that octave, [which] enables us to perceive the relationships of pitch of the several successive sounds that form a melody."18 Spurzheim-who had no musical training-took a broader view of the composite brain. He distinguished the faculty of Tune categorically from the sense of hearing and emphasized that musical ability depended on a combination of faculties, particularly "time" and "tune," a view parroted by Combe, who asserted their congenital status through the view that even "deaf and dumb persons [i.e., those who have never heard musical sounds] have an innate sentiment of measure and cadence." ${ }^{19}$ Linear melody had been the province of genius and hence a quintessentially unteachable element in music theory at least since the

\footnotetext{
${ }^{15}$ Editorial, "The Great Symphonists," Quarterly Musical Magazine and Review 8 (1826): 215-16.

${ }^{16}$ Ibid.

${ }^{17}$ George Combe, The Constitution of Man, 56.

${ }^{18}$ Anon., "Remarks on the Function of the Organ Named Melody," Phrenological Journal and Magazine of Moral Science 11 (1837-38): 33-38, here 37.

${ }^{19}$ Combe, A System of Phrenology, 374.
}

early eighteenth century. ${ }^{20}$ It is perhaps for this reason that a material faculty of melody, devoid of occultism and wrested from Nature through its amenability to "exercise," appealed to the phrenologists. But equally, it is indicative of the concept's precariously strained ambitions that the Phrenological Journal declared no faculty to have "been more puzzling to Phrenologists, or . . . the source of more disputes between them and their adversaries." 21

Notable musicians exhibited extraordinary local aptitudes that were already accepted as part of their public personae and moral stature. They thus became attractive examination subjects-whether alive or dead-for a contested science based in part on the identification of aptitudes. Take the occasion of Franz Liszt's first tours to Paris and London in 1823-24. Arriving in Paris with his father on 11 December 1823 , Liszt was famously refused entry into the Conservatoire because of his nationality. But the celebrity arising from a rumored Weihekuss from Beethoven, and his performance at the Palais-Royal for the Duke of Orleans, drew Gall to seek him out. Two casts of the boy's head were taken "to be studied": one between 1824 and 1826 by Gall, and one somewhat later by Pierre Marie Dumoutier. ${ }^{22}$ Furthermore, Liszt's earliest biographies record that he underwent a phrenological examination in London during 1825 by James Deville (17771846), a cofounder of the London Phrenological

\footnotetext{
${ }^{20}$ See Johann Mattheson's attempt at codifying melodic style as a function of harmony in Kern melodischer Wissenschaft (Hamburg: Christian Herold, 1737). See also my discussion of melodic theory in Wagner's Melodies: Aesthetics and Materialism in German Musical Identity (Cambridge: Cambridge University Press, 2013), 69-129.

${ }^{21}$ Anon., "Music.-Madame Catalani, Madame Ronzi de Begnis, Signor Ronzi de Begnis, and Mr Kalkbrenner," Phrenological Journal and Miscellany 2 (1824-25): 120-21.

${ }^{22}$ See Marie Broussais, "Liszt. Dans les collections anthropologiques du Musée de l'Homme," L'Education musicale 307, 309-10 (April, June-July 1984): 9-11, 29-31. The meeting with Gall became a curiosity for his twentieth-century biographers and still warrants a standard sentence. See, for instance, Derek Watson, Liszt (London: Dent, 1989), 16; Alan Walker, Franz Liszt: The Virtuoso Years (London: Faber, 1987), 100; and Sacheverell Sitwell, Liszt (New York: Dover, 1967), 12.
} 
Society in $1823 .{ }^{23}$ At least two biographers, Joseph d'Ortigue (1835) and Ludwig Rellstab (1843), report that Deville was willfully deceived about the fifteen-year-old Liszt, who was initially presented as a "lazy boy, devoid of natural talents, a boy whose family did not know what to do with him" (d'Ortigue). Yet in a dance of social credibility the cranial examination seemingly uncovered Liszt's musical gifts with an anointing ritual: "Deville touched the boy's head and said, then and there, strongly affected, 'Have you given him a chance with music? That would certainly be my advice'" (Rellstab). ${ }^{24}$

The extent to which there may be any truth in this anecdote is less important than the fact that both biographers deemed it of such interest to readers that each dedicated a full paragraph to it in relatively compressed accounts of Liszt's life. During the 1840s, moreover, Schumann and others drew on the related science of physiognomy to validate aggrandizing comparisons between Liszt and Napoleon. ${ }^{25}$ Indeed, Liszt continued to prove an attractive subject: Michel-Arthur Castle devoted a monograph to his character in relation to his cranial topography, ${ }^{26}$ and Samuel Wells, editor of the American Phrenological Journal, devoted an article to his facial contours, using an engraving based on a carte de visite, and included his stylized portrait in a selective pantheon of com-

${ }^{23}$ James Deville's two books make no reference to Liszt's examination: see Outlines of Phrenology, as an Accompaniment to the Phrenological Bust (London: J. De Ville, 1828); and Manual of Phrenology as an Accompaniment to the Phrenological Bust (London: J. De Ville, 1835).

${ }^{24}$ "The First Biography: Joseph d'Ortigue on Franz Liszt at Age Twenty-Three," trans. Vincent Giroud, ed. Benjamin Walton, in Franz Liszt and His World, ed. Christopher Gibbs and Dana Gooley (Princeton: Princeton University Press, 2006), 314-15; “Ludwig Rellstab's Biographical Sketch of Liszt," ed. and trans. Allan Keiler, ibid., 350.

${ }^{25}$ On this topic, see particularly Dana Gooley, The Virtuoso Liszt (Cambridge: Cambridge University Press, 2004), $87-94$.

${ }^{26}$ Michel-Arthur Castle, Étude phrénologique sur le caractère original et actuel de Mr. François Liszt (Milan: Redaelli, 1847); for an overview of the interactions between Castle and Liszt, see also Pauline Pocknell, "Le Liszt des phrènologues: ou Liszt, Castle, la Comptesse et la Princesse," in Ostinato rigore: Revue internationale d'études musicales 18 (2002): 169-83. posers for his 1866 book New Physiognomy (see plate 2). ${ }^{27}$

Authority was a two-way street, in other words: the subject being examined bestowed authority on the scientific system, just as the phrenological examination confirmed the aptitude of the subject. A large number of articles convey the measurements and conclusions from examinations of performers and singers, from German octave virtuoso Friedrich Kalkbrenner to Italian sopranos Angelica Catalani and Giuseppina Ronzi de Begnis, speculating on the combination of aptitudes each possessed. (This treatment was invariably positive: I have not found a case in which the science was used publicly to diagnose a "bad" musician.) With Liszt, d'Ortigue is most explicit: "Mr Deville .. Was delighted to have found such justification for the truth of his system." 28 In other cases, though, the effect was reversed. Combe's reported failure to diagnose an opera singer as "having large Tune" in 1825 laid him open to ridicule and necessitated a public explanation. ${ }^{29}$ Deville was similarly caught out when examining the renowned Whig writer Harriet Martineau and, left spluttering: "said it was not fair,-desired to do it all over again,to come to our house and try, and so forth." 30 Public confirmation of "phrenological science" was, it seems, forever retrospective.

Dead composers were no less in demand for this reason. As is well known, Beethoven's skull was exhumed twice: in 1863 (along with Schubert's), for reinternment in new tombs; and in 1888 , for relocation to Vienna's Zentral-

\footnotetext{
${ }^{27}$ Samuel Wells, "Abbé Franz Liszt: The Confessor-Musician," American Phrenological Journal 48 (September 1868): 88-91, here 88; see also Wells, New Physiognomy (New York: Samuel R. Wells, 1870), 528-31, here 531.

${ }^{28}$ "The First Biography," Liszt and His World, 315.

${ }^{29} \mathrm{~A}$ letter to the journal requested clarification about a story circulating that Combe diagnosed a famous singer as having very little "tune" faculty; Combe answered that he merely measured the head of the musician and, in contrast to the musician's own measurements, declared his cranial tune faculty to be "not large." He explained this by stating that it was not the tune faculty alone but the combination of time, tune, ideality, secretiveness, concentrativeness, and imitation that made musical talent. See "Letter from Mr A_ D_ to Mr Combe," Phrenological Journal and Miscellany 3 (1825-26): 98-101. ${ }^{30}$ Harriet Martineau, Autobiography, ed. Maria Weston (Boston: James R. Osgood, 1877), 297.
} 


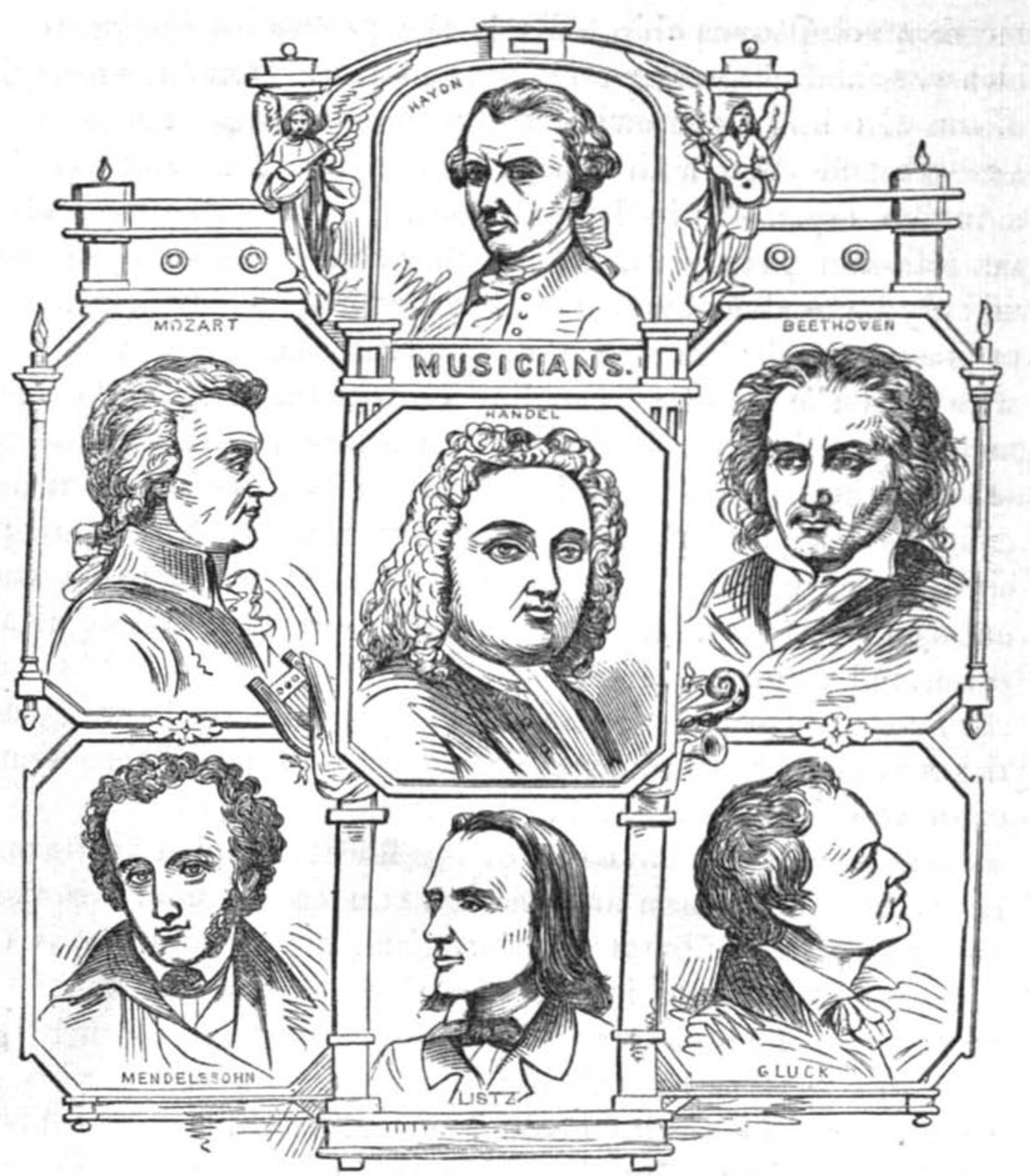

Plate 2: Samuel Wells's pantheon of composers, with Liszt at the bottom middle, in New Physiognomy (New York: Fowler \& Wells, 1866), p. 528.

Credit: Boston Medical Library, within the Francis A. Countway Library of Medicine.

friedhof. Gerhard von Breuning, author of a short essay on the reinternment, reflected that in 1863 the skulls of Beethoven and Schubert interested phrenologists because of their difference: "They seemed to reflect the characteristics of the composers' works. The walls of Beethoven's skull exhibit strong density and thickness, whereas Schubert's bones show femi- nine delicateness. ${ }^{\prime 31}$ In other words, the material presence and empirical availability of the

${ }^{31}$ Gerhard von Breuning, "Die Schädel Beethovens und Schuberts," Neue freie Presse (17 September 1886); Eng. trans. Hannah Liebermann, Beethoven Journal 1-2 (2005): 59. It is indicative that Breuning's statement faithfully reproduces Schumann's gendered reading of Beethoven and 
objects, as well as the medical training of the observers, did little to distinguish Breuning's conclusions from the amateur speculations of the Quarterly Musical Magazine and Review back in 1826: both merely co-opted the putative science to validate existing judgments about musical character.

Theft of, and unauthorized access to, composers' skulls is harder to document, of course, but the evidence suggests notable skulls remained an object of fascination. Schindler reported to Ignaz Moscheles that the gravedigger of Währing cemetery was approached with a bribe of 1,000 florins to remove Beethoven's head before burial. ${ }^{32}$ And at least one account in the Musical Times relates how Haydn's skull was stolen from his grave in 1809 by "two students of Gall's phrenology-the Esterhazy secretary, Karl Rosenbaum, and Johan Nepomuk Peter, the governor of the Lower Austrian provincial prison," and that deliberations over the object's ownership continued as late as 1932 before its eventual restoration to his skeleton in 1954.33

Even such isolated statements and anecdotes-devoid of the rigor desired of historical evidence-may be taken as referring to a single discursive object: mind-brain relations accessed via musical aptitude, however indefinite its horizon may be. They indicate a substratum of ideas that defined a field of social and cultural knowledge, a space in which amateur musicians in particular were aware of scientific endeavor and responded to its potential. Aptitude seemingly could be cultivated through special knowledge; phrenology laid claim to the vanguard of science. Hence the long established, if mutable, concept of musical genius-whose self-generated artworks mystified the process of creative invention-became a site of particular tension, provoking deterministic theories of music education and composition.

Schubert in his essay on the latter's C-Major Symphony. See Schumann, "Die 7te Symphonie von Franz Schubert," Neue Zeitschrift für Musik 21 (10 March 1840): 81-83.

${ }^{32}$ Anton Schindler to Ignaz Moscheles (4 April 1827), in Letters to Beethoven and Other Correspondence: 18241828, trans. and ed. Theodore Albrecht, 3 vols. (Lincoln: University of Nebraska Press, 1996), III, 214-17.

${ }^{33}$ Anon., "The Skull of Joseph Haydn," Musical Times 73 (1932): 942-43, here 942.

\author{
Pedagogy as Praxis: \\ BRAIN Size AND EXerCise
}

The efficiency of the blacksmith's right arm and of the philosopher's brain depends upon the same law. ${ }^{34}$

The second edition of Spurzheim's The Physiognomical System (1815) situates education within a broader cultural endeavor to "perfect mankind"; but since all faculties of the mind are innate, this perfecting can only take place where faculties already exist in an individual: "For education is nothing but exercise, cultivation and direction." After accounting for the contributing factors of nutrition and climate, Spurzheim points to exercise as increasing organ size: "This may certainly happen in the brain as well as in the muscles." 35 In other words, he allowed for the possibility of effecting the development and growth of an organ by exercise of its function. Pianists' fingers complicated this otherwise straightforward claim, for they failed to change shape with practice. This anomaly led Spurzheim to qualify that increased aptitude in the absence of physical growth also marks the effects of such education, a caveat to which I will return.

The popular appeal of phrenological science in Britain arguably relates to the close fit between its seemingly empirical route to selfbetterment, and the belief in self-help that guided the behavior of Britain's middle and working classes within a laissez-faire economy and a nonrevolutionary political regime. As Jan Goldstein points out, Spurzheim and Combe accentuated this aspect of phrenology for the British public by adding to the roster of brain organs "new ones that spoke to the value of work discipline: 'conscientiousness, ' time,' 'order,' 'concentrativeness." "'36 The goal of individual and social perfectibility carried with it a

\footnotetext{
${ }^{34}$ James Simpson, The Philosophy of Education, 2nd edn. (Edinburgh: Adam \& Charles Black, 1836), 91.

${ }^{35}$ Spurzheim, The Physiognomical System of Drs. Gall and Spurzheim, 2nd edn. (London: Baldwin, Cradock \& Joy, $1815 \mid, 552,555$.

${ }^{36}$ Jan Goldstein, "Bringing the Psyche into Scientific Focus," The Cambridge History of Science, vol. 7: The Modern Social Sciences, ed. Theodore M. Porter and Dorothy Ross (Cambridge: Cambridge University Press, 2003), 13153 , here 151
} 
moral imperative that interlocked with the civic and aspirant, mercantile environment, encouraging objections about the scientific method to be overlooked.

By contrast, the controversial view that changes of mental function are always accompanied by material changes in the brain were supported by prominent academic materialists: "Is phrenology therefore true to its minutest application? .. I cannot but say, truly it is so," remarked Carl Vogt, Professor of Zoology in Giessen and, later, Geneva. ${ }^{37}$ A corollary to this view was that the areas of an individual's brain are congenital, hence remain fixed to a certain extent; prominent negative traits could not be removed, leading practitioners to advise surveillance of such individuals. ${ }^{38}$ But the evidence was contested. The objection voiced by physiologist Johannes Müller, among others, that local injuries to the brain appear not to alter intellectual faculties (mapped phrenologically onto the injured regions) undermined any assumptions that phrenology must lead to materialism. This view was later denounced as "obviously false" by the century's leading historian of materialist philosophy, Friedrich Lange, who by 1865 sought to distance his subject from the claims of this "crudest form" of brain-mind theory. ${ }^{39}$

Materialist philosophies of mind were themselves controversial, not only because they questioned existing orthodoxy, but also because they threatened the social order built upon it. By reifying human endeavor within a universal physiological condition they appeared to loosen the moral and religious fabric of society, promoting space for pantheistic and atheistic thought, while asserting each individual's innate capacity for self-improvement and potential social advancement regardless of class, birth, and social graces. For many, though, the premise of equating mind with brain simply appeared prima facie reductionist. "Is it," asked the con-

\footnotetext{
${ }^{37 " D i e}$ Phrenologie ist also wahr, bis in die kleinste Applikation hinein? . . . Ich kann nicht anders sagen, als: Wahrlich, so ist's. Es it wirklich so." Carl Vogt, Bilder aus dem Thierleben (J. Rütter: Frankfurt am Main, 1852) 445. ${ }^{38}$ See Cooter, Cultural Meaning of Popular Science, 78-79. ${ }^{39}$ Friedrich A. Lange, A History of Materialism and Criticism of Its Present Importance, trans. E. C. Thomas, 3 vols. (London: Trubner, 1877-81), III, 118, 305.
}

servative Quarterly Review: "that there is no other difference between a man and an oyster, than that the one possesses bodily organs more fully developed than the other; that all the eminent powers ... of reason, reflexion, imagination, and memory, the powers which distinguish a Milton, a Newton, and a Locke, are merely the function of a few ounces of organized matter called the brain; and that, as soon as this is dissolved, the being which possessed those powers, perishes altogether!" 40 This attack on a prominent Fellow of the Royal Society, William Lawrence, was occasioned by the publication of his Natural History of Man (1819) and his lectures for the Royal College of Surgeons (1816), both of which he was later forced to withdraw when the Lord Chancellor declared them blasphemous (annulling Lawrence's copyright). ${ }^{41}$ While such publications were frequently censored, they had long been accessible to the wealthy and discreet, and, as James Secord explains, "were sold in much the same way land sometimes through the same channels) as pornography." 42

In 1790s London, the leading materialist, whose ideas established a platform on which later discourses on phrenology could appear credible, was the polymath Erasmus Darwin. His two-volume discourse on material and medical science, Zoonomia (1796), defined mental ideas as the motion of fibers in our sense organs, and the patterns of these motions. In an addendum he continued that the belief in ideas as innately mental events, separate from everyday nature, is nothing but a "fanciful hypothesis, like the stories of ghosts and apparitions which ... amuse the credulous without any foundation in nature." 43 Hence the immediate objects of thought are simply the movements of the relevant neural fibers, which underscore a sensationalist epistemology in which mind and body are wholly synonymous. Those who

\footnotetext{
${ }^{40}$ Editorial, "Abernethy, Lawrence, \&c. on the Theories of Life," Quarterly Review 43 (July 1819): 2-34, here 14.

${ }^{41}$ William Lawrence, An Introduction to Comparative Anatomy and Physiology (London: J. Callow, 1816).

${ }^{42}$ James A. Secord, Visions of Science: Books and Readers at the Dawn of the Victorian Age (Chicago: University of Chicago Press, 2014), 187.

${ }^{43}$ Erasmus Darwin, Zoonomia; or The Laws of Organic Life, 2 vols. (London: J. Johnson, 1796), II, 643.
} 
would defend Darwin's assertion were unable to hold a professorship anywhere in Europe or the United States, for state and religious authorities assumed atheism, pantheism, and materialism were "enemies of the status quo" and sought "to crush" them, as Edward Reed put it. ${ }^{44}$ Even the dissemination and publication of such ideas in most European countries after 1815 became punishable by imprisonment.

Spurzheim explicitly maintained compatibility between phrenology and religious belief for this reason. "A natural philosopher, who inquires into the laws of phenomena, cannot be an atheist," he implored in 1815: "he cannot consider the admirable and wise concatenation of all nature, the mutual relation between all things, as destitute of a primitive cause. He is obliged, according to the laws of thought, to admit such a cause, a supreme understanding, an all-wise Creator." 45 Here a plurality of materialisms allowed that mind and brain could follow the same laws without themselves being identical phenomena, and phrenologists were adept at equivocating over this matter. Given the later deterministic and materialist principles-drawn from a spectrum of individual formulations, from Cabanais to Magendie, Vogt to Moleschott, Babbage to Combe - that underpin phrenological discourse, it may seem surprising that a majority of commentators followed Spurzheim in viewing the brain as physically mutable rather than forever fixed in determining identity as a balance sheet of aptitudes and deficiencies. This combination of the brain's physiological innateness with environmental plasticity caused a degree of confusion within the British press. ${ }^{46}$ But, unlike principles of atavism and degeneration applied to aesthetics later in the century, phrenology

${ }^{44}$ Edward S. Reed, From Soul to Mind: The Emergence of Psychology from Erasmus Darwin to William James (New Haven: Yale University Press, 1997), 44.

${ }^{45}$ Spurzheim, The Physiognomical System, 491-92.

${ }^{46}$ See, for instance, the need for public clarification in 1825 :

"That the mind can be altered materially by education, is of course opposed to the opinion, that it is totally 'dependent on organization;' but it is not opposed to the doctrine, that the organization of the brain is dependent on the development of the faculties"; in "On Materialism," Phrenological Journal and Miscellany 2 (1824-25): 15051. allowed for changes in inherited mental faculties, and most believed that education could and should be applied to increase positive traits or strengthen a deficient faculty through guided "exercise" (whose nature and supervision would naturally fall to the phrenologist).

Perhaps the most direct statement on the matter comes from Deville, the London-based examiner of Liszt we met earlier. According to a published lecture summary, he cautioned that after neglecting to follow his advice to resist language studies for between two and four years, an eight-year-old boy he examined is, fifteen years on, "now little better than an idiot," and that a promising mathematician, examined age six, ignored advice not to overwork his "organ of Number" and consequently suffered mental weakness: "In his head [this organ] is now evidently smaller than in casts taken at four and six years of age." 47 Deville's tales of successfully cultivating mental faculties stretch credulity further still, but illustrate both the coercive moral imperative associated with phrenology and the contemporary hope that such methods would lead to self-betterment, economic prosperity, and social advantage.

It is also a measure of the authority of phrenological judgment that such stories could appear in a professional journal. To take one example, Deville examined a nineteen-year-old undergraduate's head, revealed him to have potential but declared him "too positive and selfwilled to go by the rules laid down for the acquirement of knowledge, ... . [he has] less knowledge at nineteen than he ought to have possessed at twelve or fourteen." ${ }^{\prime 4}$ Perhaps not coincidentally, this matched his Cambridge tutor's verdict, and the student redoubled his dedication to academic work. A second head cast was taken two and a half years later showing "a diminution of fully half an inch at SelfEsteem and Firmness, and a large increase of all the intellectual and moral organs." 49 In all cases,

\footnotetext{
${ }^{47}$ Editorial summary of James Deville, "Account of a number of cases in which a change had been produced on the form of the head by education and moral training," Phrenological Journal 14 (1841): 32-38, here 33.

${ }^{48}$ Ibid., 35.

${ }^{49}$ Ibid.
} 
the maximum growth or shrinkage was half an inch, aligning with Combe's caveat about education, namely that while organ size "determines power" and education increases the "energy" permitted by the size of a faculty, "size [nevertheless] fixes a limit which education cannot surpass." 50

London caricaturists readily satirized the enterprise. Plate 3, a sketch entitled "bumpology" by George Cruikshank from 1826, shows Deville examining a young man while his mother looks on and an assistant records the examination results: "Very large wit no. 32." The image also shows a note under the phrenological skull on the table; it records a prominent murderer John Thurtell as a "craniologically excellent character," mocking the hope that criminals could be identified by head shape while simultaneously drawing attention to readers' fear of what may be revealed in plain sight. With reference to cranial enlargement, the frontispiece of Cruikshank's 1827 collection of phrenological caricatures (plate 4) depicts three deformed men, alive and interacting but with heads marked with the divisions of phrenological organs; each has a grotesquely misshapen cranium, in effect warning of the potential to cultivate abnormality through perverse science.

Deville's enterprise also highlights the assumption, unspoken if not unthought, that a concept of the "normal" brain has crystallized as the midpoint of potentially enhanced and deficient faculties-neither too large nor too small. The social concept is manifest in the generic plaster bust Deville sold from 1824, detailing the different brain organs and their desired proportions. But it taps into a more pernicious "power of normalization" that Michel Foucault has identified with a network of institutions in the early decades of the century, wherein pathological conditions were identified by expert medico-legal opinion via a kind of "scaled-down criminality for children [adopting] the language used by parents or by the

${ }^{50}$ George Combe, Elements of Phrenology, 3rd edn. (London and Edinburgh: Simpkin \& Marshall, and John Anderson, 1828), 166.

${ }^{51}$ Michel Foucault, Abnormal: Lectures at the Collège de France 1974-75, trans. Graham Burchell (New York: Picador, 2003), 26, 33. morality of children's books." ${ }^{11}$ Hence "selfesteem" and "stubbornness / firmness" become negative organs that children should avoid developing extensively. The solution, from such expert opinion, was either expiatory or therapeutic; phrenology advised the latter, criminology, the former.

Despite the ridicule, certain respected scientists took the concept of brain mutation more seriously. The Scottish physician William Gregory declared such cases of changes in head shape "a priori probable, on the physiological principle that exercise has a tendency to enlarge an organ; and that now [after Deville's 1841 lecture] we begin to possess actual evidence that changes do take place." 52 As an undergraduate, Charles Darwin privately sympathized, seeing in the process evidence of free will: "One is tempted to believe phrenologists are right about habitual exercise of the mind altering form of the head, and thus these qualities become hereditary. When a man says I will improve my powers of imagination, \& does so,- -is not this free will[?]"153 In the case of music, it seems that a critical mass (minimum initial brain size) was needed, and the ratio of size to activity was not always assumed to be proportionate, a circumstance that Combe used to justify enthusiastic musical practice in the absence of increased musical skill. ${ }^{54}$ Here the lack of talent finds its own casuistic explanation through the science.

But to what extent do Deville's lecture and the chain of statements preceding it reflect a consensus of opinion about music education in Britain? To the extent that we can reconstitute a system of nineteenth-century thought based on discourse, the answer is: closely. Commentators on British education were, almost without exception, inclined to the view that cumulative practice, iteration, and physical (sense-

\footnotetext{
${ }^{52}$ Deville, "Account of a number of cases," 37.

${ }^{53}$ Charles Darwin, The M Notebook (1838): 30. See http:// darwin-online.org.uk/content/frameset? viewtype $=$ side $\&$ itemID=CUL-DAR125. $-\&$ pageseq $=1$ [accessed 17 June 2014].

54"A certain degree of size must be possessed to render it capable of increase. A lady whom [I] knew practiced music for years, in the hope of improving her musical talent, but at last gave up the attempt in despair." Deville, "Account of a number of cases," 38 .
} 


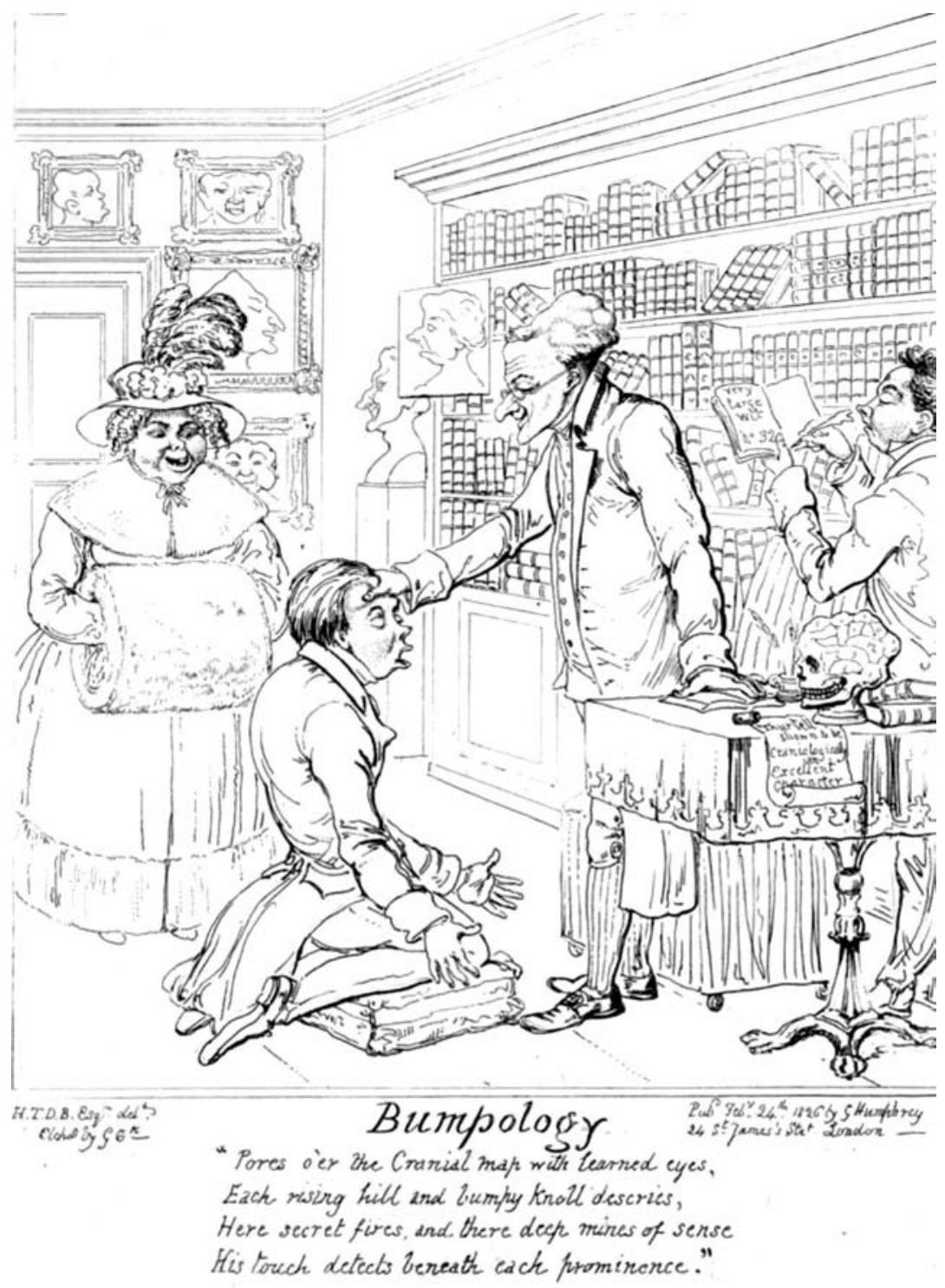

Plate 3: George Cruikshank caricature of phrenology. Etching, 24 February 1826.

Credit: British Museum, 1859, 0316.188.

led, experience-based) activity were essential for the cultivation of faculties. As we have seen, this was a purely material process for phrenologists. The abstraction of intellectual potential through logic, theory, and speculative metaphysics would cultivate little. "Speak to a child of music," Spurzheim had explained, "but prevent him from hearing it, and never permit him to play on any musical instrumentcan you imagine that his faculties of tune will be exercised?"55 Ironically, against the materialist leanings of this statement, Hegel, in his critique of Kant, had voiced the same methodological plea within an idealist tradition: "We ought, says Kant, to become acquainted with the instrument before we undertake the work for which it is to be employed. . . But the

\footnotetext{
${ }^{55}$ Spurzheim, The Physiognomical System, 555.
} 


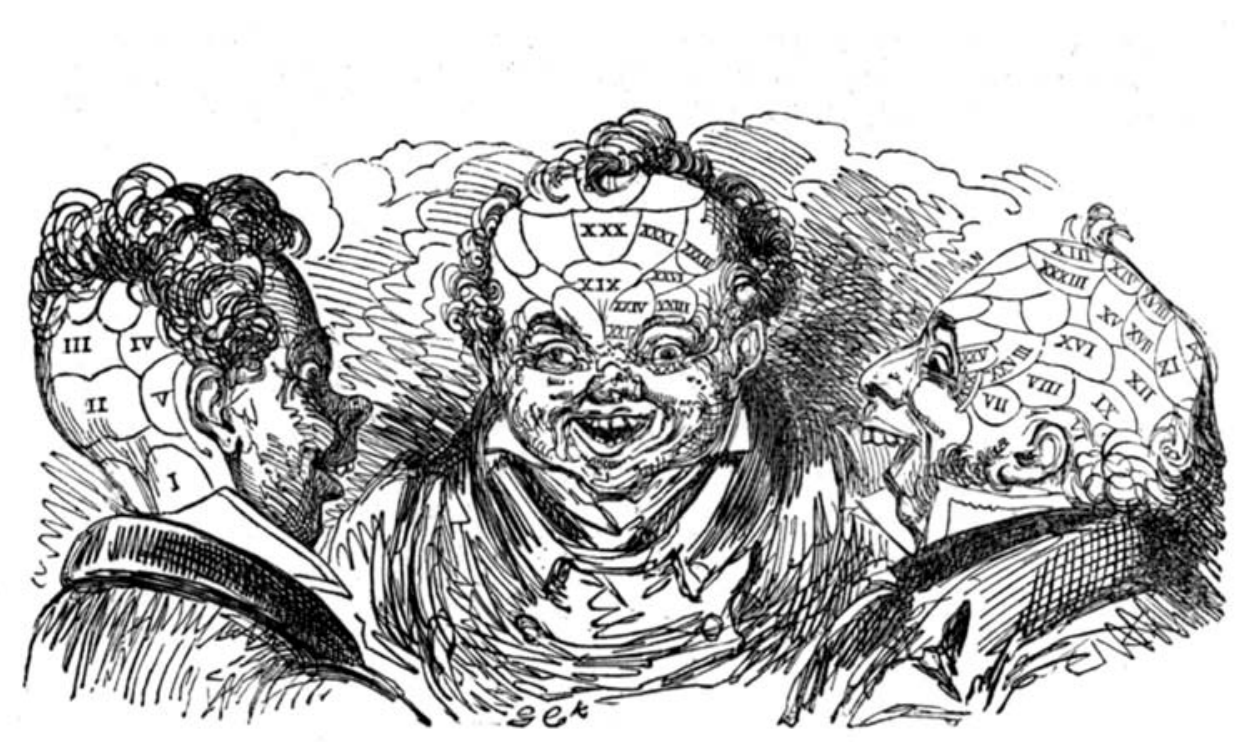

Plate 4: George Cruikshank, frontispiece to Phrenological Illustrations, or An Artist's View of the Cranological System of Doctors Gall and Spurheim (London, 1827).

Credit: British Museum, 1978, U.3020.1.

examination of knowledge can only be carried out by an act of knowledge. To examine this so-called instrument is the same thing as to know it. But to seek to know before we know is as absurd as the wise resolution of Scholasticus, not to venture into the water until he had learned to swim." ${ }^{\prime \prime 6}$ That this fulcrum applies equally to metaphysics, materialist phrenology, and music pedagogy suggests the degree to which commentators in each tradition confronted ideas from the same discourse. This speaks less to an order of generality than one of resemblance, for access to musical as well as, say, anatomical knowledge, depended on haptic activity and the cognitive challenges of manual work. Even idealist metaphysics, for Hegel, deals in knowledge as a fluid substance that philosophers manipulate. Prior to an historical separation of thinking from doing (with

${ }^{56} \mathrm{G}$. W. F. Hegel, The Logic of Hegel, from the Encyclopaedia of the Philosophical Sciences, trans. William Wallace (Oxford: Clarendon Press, 1892), §10, 17. the assembly line), ${ }^{57}$ musicians, surgeons, and certain idealists thus resembled each other in their material dependence on objects of knowledge. Amid differing qualities of adherence to materialism, this regime coexisted comfortably with phrenology where the dominant social ethos of self-betterment (or "mental improvement" as it was usually called) was rationalized in terms of repeated exercise of function concerning those objects, and tangible brain growth.

Officially, the national discourse on educational method remained detached from phrenology, but continuities between them were nevertheless present. Often educationists were themselves prominent phrenologists. This was the case with the Scottish lawyer James

\footnotetext{
${ }^{57}$ For a discussion of Frederick Winslow Taylor's influence over work in which "all possible brain work [is] removed from the shop and centered in the planning or laying-out department," see Matthew B. Crawford, Shop Class as Soul Craft: An Inquiry into the Value of Work (New York: Penguin, 2009), 38ff.
} 
Simpson (1781-1853), who lectured in England on educational matters that included Lancastrian education and the monitor system throughout the 1830s and 40s, appearing as a witness for seven consecutive days in 1837 before the House of Commons committee on national education in Ireland. ${ }^{58}$ The previous year, his 288-page book on education had applied phrenological principles to children's education in all but name:

To be improved each and every faculty must be positively exercised. Perceptive instruction is notoriously insufficient to give mechanical skill ... [the observing and reflective faculties] must themselves work in a long course of active practice, to reap the reward of talent. ... The law of exercise is of universal application. It is a fundamental law of nature, that all the capacities of man are enlarged and strengthened by being used. From the energy of a muscle, up to the highest faculty intellectual and moral, repeated exercise of the function increases its intensity. The efficiency of the blacksmith's right arm and of the philosopher's brain depends upon the same law. The bodily force, the senses, the observing and reasoning faculties, the moral feelings, can only be improved by habitual exercise. ${ }^{59}$

It is striking in this context that the Viennese music pedagogue Carl Czerny explains the purpose of his composition treatise, op. 600, as the practical application of a priori knowledge; before studying models of form and embarking on exercises, students "are supposed to possess an entire theoretical knowledge of composition, namely of harmony, counterpoint, the correct conduct of the parts, \&c.; and therefore nothing need be said here on these subjects." 60 The goal is skillful activity (delineating form) rather than new knowledge; the latter, uncultivated through activity and exercise, appears of little value for a practical school, or what Hindemith a century later would call compositional craft.

\footnotetext{
${ }^{58}$ See Edward Irving Carlyle, "Simpson, James," Dictionary of National Biography, 63 vols. (London: Smith \& Elder, 1885-1900), vol. 52, 270.

${ }^{59}$ James Simpson, The Philosophy of Education (Edinburgh: Adam \& Charles Black, 1836), 91. Simpson collaborated with George Combe in establishing the Phrenological Journal (1823-47), to which he also contributed.

${ }^{60}$ Carl Czerny, School of Practical Composition: or, Complete Treatise on the Composition of all Kinds of Music, Op. 600, trans. John Bishop (London: Cocks, 1848), iii.
}

While composition treatises have prescribed progressive "exercises" at least since J. J. Fux's Gradus ad Parnassum (1725), the oblique application to musical studies of a materialist work ethic acting on "brain fibres" and finger dexterity, akin to physical exercise working on muscle fibers and sinews, is new to the early nineteenth century and its advocacy of sensory epistemology, of knowledge through physical experience. ${ }^{61}$

Czerny was a teenage teacher of piano and composition in Vienna when Gall's public lectures first drew attention to his theory of the brain and mental faculties. By 1802, when Czerny turned eleven, phrenology had gained such currency that the French philosopher Charles Villers could ask: "who hasn't heard of Gall and his skulls?"62 As well as circulating within the city's culture, Czerny had access to Gall's new science through his most important professional relationship: Beethoven's Tagebuch (1812-18) records the composer's acquaintance with Gall's doctrine in a comment about his nephew Karl. ${ }^{63}$ In the absence of concrete evidence, we can only speculate as to whether Czerny encountered materialist ideas about "exercise" in the context of phrenology, but it would seem his attitude toward mental and muscular repetition is worth examining in this context. Not least because his first piano method (Hundert Übungsstücke, op. 139) appeared in 1827 at precisely the time Spurzheim clarified the importance of exercises and of praxis for all educational reforms:

I employ the word exercise as synonymous with putting into action. Now the first law of this kind is,

\footnotetext{
${ }^{61}$ For arguments relating Mary Shelley's Frankenstein to "bodies" of musical knowledge, see Leslie David Blasius, "The Mechanics of Sensations and the Construction of the Romantic Musical Experience," Music Theory in the Age of Romanticism, ed. Ian Bent (Cambridge: Cambridge University Press, 1996), 3-24, esp. 17-18.

${ }^{62}$ Charles Villers, Lettre à George Cuvier, de L'Institut National de France, sur une Nouvelle Theorie du Cerveau, par le Docteur Gall (Metz: Colligon, 1802), 34.

${ }^{63}$ "Gall observes that a cold bath is not beneficial to the growing body: he even recommends that one should not allow young people between the ages of 14 and 21 to take cold baths, but only when the body is fully grown." See Maynard Solomon, "Beethoven's Tagebuch of 1812-18," Beethoven Studies 3, ed. Alan Tyson (Cambridge: Cambridge University Press, 1982), 193-285, here 270.
} 
that exercise strengthens powers. . . . Each mental power, if it be sufficiently cultivated, grows more energetic, whilst, if neglected, it shows less activity. ...I is time to abandon the immense error, that words and precepts are sufficient to call internal feelings and intellectual faculties into active exercise. ${ }^{64}$

By comparison with Vienna's musical environs, Czerny "prescribed to piano players 'labor' [Arbeit] on their instrument," Grete Wehmeyer argues, "at a time in Europe when activity and labor were declared to be the highest values for bourgeois life." 65 The tutor advocated working through daily exercises, in composition as well as in keyboard dexterity, as the only guarantee of success. This applied to both professionals and amateurs. ${ }^{66}$ If exercises in keyboard technique and composition are not directly comparable, the implication of a common epistemology nevertheless emerges: that both are rooted in the cognitive experience of sensation. ${ }^{67}$ Speaking of piano methods by J. N. Hummel and Louis Adam, Leslie Blasius has explicitly identified finger training with com-

${ }^{64}$ Spurzheim, View of the Elementary Principles of Education [1821], 2nd edn. (London: Treuttel, Würtz, and Richter, 1828), 96-97, 103 .

${ }^{65}$ "Czerny verordnete den Klavierspielern 'Arbeit' (Pianoforte-Schule, vol. 3) am Instrument in einer Zeit, als in Europa für das bürgerliche Leben Tätigkeit und Arbeit zu den höchsten Werten erklärt . . . wurden"; Grete Wehmeyer, "Carl Czerny" Die Musik in Geschichte und Gegenwart, 2nd edn. (Kassel: Barenreiter, 2001), col. 229. ${ }^{66}$ Just as Adam Liszt assured his son's former teacher in 1824 that "I still have [Franz] practice scales and etudes with a metronome and do not deviate from your principles" ("Ich lasse ihn noch immer Scala und Etuden beim Metronome spielen und gehe nicht ab von Ihren Principien"I), Czerny explained in his 1837 Letters to a Young Lady: "I therefore most earnestly recommend you to practice daily, with untiring diligence and the greatest attention, all the five-finger exercises in both hands, which you will find at the beginning of my Pianoforte School." See Adam Liszt to Czerny (29 July 1824), cited in La Mara, Classisches und Romantisches aus der Tonwelt (Leipzig: Breitkopf \& Härtel, 1892), 249; and Carl Czerny, Letters to a Young Lady on the Art of Playing the Pianoforte, trans. J. A. Hamilton (London: Cocks, 1837), 8-9. For an assessment of Czerny's role as Liszt's tutor, see James Deaville, "A Star Is Born? Czerny, Liszt, and the Pedagogy of Virtuosity," in Beyond the Art of Finger Dexterity: Reassessing Carl Czerny, ed. David Gramit (Rochester: University of Rochester Press, 2008), 52-66.

${ }^{67}$ See Grete Wehmeyer's characterization of Czerny's attitude to pedagogy as "industrial work ideology" in Carl Czerny und die Einzelhaft am Klavier (Kassel: Bärenreiter, 1983), $153 f f$. positional theory in this sense: "The student learns this simple theory by association with the sensation of the hands. In fact the student learns more. The progression through the text, through the accompanying didactic etudes, through other studies, through excerpts, is a way of rationally increasing the quality and complexity of sensations and associations, of creating a rich and replete musical experience." 68 This theory operates within a liminal space between organic and mechanic, where hands were figured as both natural organs and artificially trained instruments. Equally, like the "natural law" Spurzheim saw between the mutable shape of the brain and the mutable cranium, ${ }^{69}$ mutable genres and musical forms, for Czerny, also "depend . . . on natural laws."70 Together these position both humans and their art as products of nature, and it is for this reason that Spurzheim concluded his comments on education thus: "those who endeavour to educate men ought to begin by studying the nature of man."71

Pursuing this theory of equivalence, several writers find in the hands of pianists a musical analogue to the phrenological mind (i.e., an aggregate of mutable organs existing both independently and as a composite). As noted above, Spurzheim used this to qualify the assumption of a proportional ratio between mental exercise and physical size of individual faculties: "The fingers of an individual, habituated to play upon the pianoforte, do not always increase [in size], but their motions become more facile and less easily fatigued, than in a person who seldom makes use of his hands."72 By the early nineteenth century, virtuoso hands had become an object of fetishistic interest, as the mediator between mind and instrument, or the "instrument of instruments" as James Q. Davies puts it in his cultural study of virtuoso physiologies. ${ }^{73}$

Aestheticization of their physical appearance

\footnotetext{
${ }^{68}$ Blasius, "The Mechanics of Sensation," 13.

${ }^{69}$ Spurzheim, The Physiognomical System, 224.

${ }^{70}$ Czerny, School of Practical Composition, 2.

${ }^{71}$ Spurzheim, The Physiognomical System, 558. ${ }^{72}$ Ibid., 555.

${ }^{73}$ James Q. Davies, Romantic Anatomies of Performance (Berkeley: University of California Press, 2014), 102.
} 
meant aestheticization of their mediating physicality, prompting a culture of reading physique in light of something else. "At the threshold of experience," Davies continues (citing Aristotle's proposition that "the soul is as the hand"), "hands wove inner and outer together. ... This hand was a sign, and it acted in signs. The work it performed, the language it spoke, its very physiognomy was always 'engaged to' or 'on behalf of."'74 Phrenologists co-opting the same discourse did so with the aim of using the hand as a material cipher for the brain. Writing with greater professional expertise than Spurzheim, Nauenburg offered a more nuanced simile to explain mental development, drawing music and phrenology further into a single discursive field:

I imagine the activity of individual organs of the brain to be like that of muscles in the hand. The muscles of each finger are naturally stronger or weaker; in some usage the natural muscle strength is never fully developed; in others only individual fingers are used; the natural aptitude for cultivation of strength resides equally in the fingers used less, but it exists and is not at all dead. The pianist nevertheless strives for harmonious training of $e \mathrm{~V}$ ery finger; the muscle power of individual fingers operates separately and as a unity according to natural laws and any desired use. So it is with the organs of the brain; those that are by nature the largest and strongest lead sooner or later to one's most noticeable outward characteristics and determine one's areas of effectiveness in life. The weak and (relatively) small organs tend to remain behind in their development and become barely or not at all noticeable in one's outer life; hence their purely physical activity, their animal life, so to speak, in no way dies out. ${ }^{75}$

\section{${ }^{74}$ Ibid.}

${ }^{75}$ "Ich stelle mir die Thätigkeit der einselnen Seelenorgane so vor, wie die Thätigkeit der Muskeln in der Hand; die Muskeln einzelner Finger sind von Natur kräftiger oder schwächer; bei manchen Handbeschäftigungen kommen die natürlichen Muskelkräfte niemals zur vollständigen Entwicklung; bei manchen werden nur einzelne Finger gebraucht; die natürliche Anlage zur Kraftentwicklung ruht gleichsam in den weniger gebrauchten Fingern, sie ist aber vorhanden und keineswegs abgestorben. Der Pianofortespieler jedoch restrebt eine harmonische Ausbildung aller Finger; die Muskelkraft in den einzelnen Fingern wirkt gesondert und vereinigt nach natürlichen Gesetzen und zu beliebigem Gebrauche. Aehnlich die Seelenorgane; die von Natur größten und kräftigsten kommen früher oder später zur äußeren Lebensthätigkeit und bestimmen die
Beyond the basic simile, the pianist's naturally unbalanced hand becomes a paradigm for the interdependence of education and inherited "animal" condition. It is this interdependence that determines an individual's mental and physical faculties; but while young pianists aimed for evenness across the fingers in scales and passagework, it is not clear that any phrenologists advocated a normalizing agenda across faculties. Notable improviser virtuosos such as Kalkbrenner and Liszt voluntarily submitted themselves for cranial examination, and Nauenburg's strategy was doubtless to capture readers' imaginations through their hands. ${ }^{76}$

\section{LOGIER, LANCASTER, AND THe Monitorial System}

As the case of Czerny suggests, the extent to which such conjecture overlapped with theories of musical training becomes more concrete through an emphasis on practical exercises and systematic, graduated learning dictated by published tutors. There were no music pedagogical institutions in London when Spurzheim began lecturing, so phrenological ideas must be traced at the level of individual tutors. When the Royal Academy of Music opened in 1822, it listed three professors of "composition and harmony": Thomas Attwood, William Crotch, and William Shield. Two had published treatises privately (Crotch's Elements of Musical Composition [1812]; Shield's Rudiments of Thoroughbass for Young Harmonists [1815]), while the major German and French treatises appeared in translation only during the 1840s and 50s (see Table 1). In light of Spurzheim's definition of education as "exercise, cultivation, and direction," it is telling that Crotch's 1812 treatise interleaves a series of practical

Lebenswirksamkeit des Menschen; die schwachen und (relativ) kleinen Organe bleiben in der Regel in ihrer Entwickelung zurück und werden im äußeren Leben des Menschen wenig oder night bemerkbar; ihre rein physische Thätigkeit, ihr, so zu sagen, thierisches Leben stirbt deshalb keineswegs ab." Nauenburg, "Die Phrenologie in ihrer Beziehung zur Tonkunst," Neue Zeitschrift für Musik 2 (1851): 16.

${ }^{76}$ See "Music-Madame Catalani, Madame Ronzi de Begnis, Signor Ronzi de Begnis, and Mr Kalkbrenner," Phrenological Journal and Miscellany 2 (1824-25): 120-30, here 12730. 


$\begin{array}{ll}\text { Johann } & \text { Logier's Theoretical and Practical Study for the } \\ \text { Bernhard } & \text { Piano Forte, comprising a Series of Compositions } \\ \text { Logier } & \text { selected from the most Classical Works ancient } \\ & \text { and modern arranged with Inverted and Funda- } \\ & \text { mental Basses and fingered throughout: being a } \\ & \text { continuation of instruction on his system of } \\ & \text { musical education }\end{array}$

J. B. Logier A System of the Science of Music and Practical Composition, Incidentally Comprising what is

Luigi Cherubini

Gottfried Weber

Carl Czerny

A. B. Marx

Anton Reicha

\section{An Attempt at a Systematically Arranged Theory of Musical Composition}

School of Practical Composition: or, Complete Treatise on the Composition of all Kinds of Music (3 vols.)

The School of Musical Composition, Practical and Theoretical

Course of Musical Composition: or, Complete ↔) Methodical Treatise of Practical Harmony
$1827[1827]$

J. B. Logier (?)

$1837[1835]$

J. A. Hamilton

$1842[1817-21$, 1830-32]

James F.

1848 [1849] Warner

John Bishop
Augustus Wehrhan

$1854[1816-18]$
Arnold Merrick / John Bishop "tasks" for students to complete in order to inculcate through activity the knowledge gained after reading outlines of harmonic grammar and form. ${ }^{77}$ Czerny's composition treatise, op. 600, published several decades after his systematic keyboard exercises, adopts a similar approach in its emphasis: "practically employing . . . theoretical knowledge." ${ }^{\prime 78}$ Each volume bears

\footnotetext{
${ }^{77}$ William Crotch, Elements of Musical Composition (London: Longman, Hurst, Rees, Orme \& Brown, 1812), 80, 122-23.

${ }^{78}$ Czerny, School of Practical Composition, 3 vols. (1849): I, iii (original emphasis).
}

the subtitle: "Practice Perfects Theory" (Die praktische Übung krönt das theoretische Wissen), a motto Czerny's English translator found entirely justified in the context of the treatise's aim to teach form and genre progressively by example and exercise.

Two decades before Czerny's treatise appeared, the aspiring pedagogue Johann Bernhard Logier published a wide-ranging music treatise in London and Berlin simultaneously. Logier, a German of French extraction who came to England via Ireland as a literary and music entrepreneur, asserted a similar pedagogical outlook in his dictum that "to acquire facility in composition much practice is absolutely neces- 
sary." 79 The treatise's three parts address piano technique, harmony and counterpoint, and methods of instruction. He characterized his work as "relating solely to Music as a Science, and the application of that science to practical composition. ${ }^{\prime 80}$ Logier was writing for an amateur audience keen to benefit from scientific knowledge. Protesting at what he saw as the aesthetic pretentions of originality and inspiration, he asks mockingly:

How shall I begin? How shall I set about it? . . . If the pupil . . . has carefully studied the construction of period and melodies, the necessity of asking such questions no longer exists; for what beginning can be more simple .. . he draws an outline of his intended composition, fills it up with fundamental basses, extracts inverted basses, and constructs a countermelody; to which he adds the rest of this parts, dissonances, passing and auxiliary notes etc. All this is accomplished without difficulty, because the rules are all determined, and nothing is left to chance. During this process, no peculiar musical genius or feeling, no imagination or nicely-discriminating $[$ sic] musical ear is required. . . . The process here pointed out is so simple, and, it may be added, interesting, that it only requires in us the will, and the object is accomplished. ${ }^{81}$

His final statement is curiously aligned with Darwin's view of phrenology as proof of free will, but the key point for present purposes is that Logier's belief in mechanical repetition of what amounts to a permutational logic of harmony interlocks neatly with the virtual muscular work phrenologists advised for expanding a mental faculty.

The swagger behind Logier's claim that mechanical, rule-based composition is voided of genius and hence "guaranteed" was criticized candidly. A committee of sixteen "professors in London" complained that after two and a half years of training, "this boasted System began and ended by the exhibition of certain combinations of chords on a slate. . . These ... have not much more relation to Harmony and

${ }^{79} \mathrm{~J}$. B. Logier, A System of the Science of Music and Practical Composition (London: J. Green, 1827), 321 (emphasis added).

${ }^{80}$ Ibid., xii.

${ }^{81}$ Ibid., 321-22, 323 (emphasis added).
Composition, than Arithmetic has to Poetry." 82 Responding to Logier's marketing claims, the committee publicly denounced him in a pamphlet, the ensuing exchanges of which were then collated and republished separately, such was the public interest. ${ }^{83}$ The pamphlet continues that the acquisition of knowledge "must always be progressive, and is generally slow," concluding that it is hardly surprising "that any system, by which it is pretended that Science may be acquired at the expense of little time, and less labour, should be regarded with extraordinary suspicion." 84 Such a critical reception of this assembly-line approach to composition indicates Logier's treatise touched a nerve, even if his transparent advertising undermines any stable interpretation thereof, phrenological or otherwise.

In fact, the application of phrenology's materialist principles to musical studies arguably finds its truest expression in Logier's systematic approach to training pianists, and its oblique pedagogical model in England, Joseph Lancaster's monitorial system. The one involves physically playing through exercises on a rigid mechanical apparatus ("chiroplast"/Handbildner), the other saw school rooms set out mechanistically; both applied principles of systematic, efficient, practice-based learning, and both carry the burden of increasing aptitude by repetitive, mechanically guided activity. It is no coincidence that they were directly compared in at least one contemporary account, ${ }^{85}$ and

\footnotetext{
${ }^{82} \mathrm{~A}$ committee of professors in London, An Exposition of the Musical System of Mr Logier with Strictures on His Chiroplast (London: Budd and Calkin, 1818), 66-67. The authors' names are given as: "Messrs. Attwood, Ayrton, J. Beale, F. Cramer, Crotch, Dance, Ferrari, Griffin, Horsley, C. Knyvett, Latour, Mazzinghi, Neate, Novello, Ries, G. Smart."

${ }^{83}$ Ibid. See the six articles presented chronologically under the heading: "Mr. Logier's New System of Musical Instruction," Quarterly Musical Magazine and Review 1-4 (1818): 111-40. A summary assessment of the exchange is given in Bernarr Rainbow, "Johann Bernhard Logier and the Chiroplast Controversy," Musical Times 131 (1990): 193-96.

${ }^{84}$ Various, An Exposition of the Musical System, 3, 67.

${ }^{85}$ "The advantages and defects of (Logier's) system were too much exaggerated and also condemned. The professors apprehended that it would take their business out of their hands, and decried it as a piece of imprudent quackery; but there can be no doubt, as far as the Lancastrian plan is
} 
while Logier's apparatus was part of a family of orthopedic piano devices at the time, he was unusual in Georgian England for promoting serious instrumental practice, which remained "fit only for the hired help" in David Golby's words, and was seen as a "poor cousin" to the past glories of Handel's oratorios. ${ }^{86}$

To train pianists, Logier's "chiroplast" regulated finger movement and hand position. It was patented in 1814 and, as plate 5 shows, consisted of two parts: parallel horizontal brass rails above the keyboard effectively fixed the position of the pianist's wrists while playing; and movable brass "finger guides" restricted finger movement, ensuring only a vertical action in any given five-finger position. Teaching often involved multiple pianists working together at different pianos simultaneously, the advantages of which were that "all slight errors are mutually corrected, [and] the happiest emulation is excited." ${ }^{87}$ And, linked to the device, a "gamut board" placed on the music desk ensured that each written note was placed above its corresponding key.

The stated aim in Logier's first companion to the device was "to do that by an infallible mechanical means, which is now done by a long process of instruction." ${ }^{\prime 88}$ If the alleged objectivity of phrenology was visibly reinforced in lecture theaters by its scientific accoutrements-skulls, casts, busts, brain charts-the chiroplast replaced one symbol for objectivity with another. Principally, the device molded students' hands into regulated instruments, teaching basic tonal theory as corollary; but the possibility arises that the sensation of fingerwork may itself induce affective thoughts,

pursued in teaching a number (of day school pupils) together, that the same principle may be applied to music with advantage." In William Gardiner, Music and Friends: or, Pleasant Recollections of a Dilettante, 2 vols. (London: Longman, Orme, Brown, and Longman, 1838), II, 649.

${ }^{86}$ David J. Golby, Instrumental Teaching in Nineteenth Century Britain (Farnham: Ashgate, 2005), 66. For a discussion of early-nineteenth-century orthopedic devices for training pianists, see Davies, Romantic Anatomies of Performance, 109-15, 156-60.

${ }^{87} \mathrm{~J}$. B. Logier, Sequel to the First Companion to the Chiroplast (London: J. Green, 1827), 2 (emphasis added).

${ }^{88} \mathrm{~J}$. B. Logier, The First Companion to the Royal Patent Chiroplast, 5th edn. (London: I. Green, 1822), unnumbered dedication page. as Blasius has intimated, and Logier explicitly asserts his chiroplastic exercises will arouse in students "a desire for composing .... in the style of variations . . . whilst they are intended merely to improve the hand, [they] may also unconsciously improve the head." 89 This putative development of compositional skill through finger activity is effectively a phrenological statement in this context. Plate 6, from Logier's first companion, illustrates the progressive, didactic steps from five-finger exercise to twopart counterpoint.

Logier actively promoted his device in Ireland, France, the German states, and Great Britain, where he experienced a degree of financial success but was accused of charlatanism. By 1818 at least one academy for "chiroplastic" instruction had been established, 90 and Cruikshank, the future satirist of phrenology, responded with the caricature shown in plate 7. It sides with the accusers in showing Logier prancing atop a piano, satirizing his method of teaching piano simultaneously to a group of "500" children; the text parodies chestnuts of music theory such as the natural origins of tonality, the uncertain harmonic basis of the minor triad, and the avoidance of parallel fifths and octaves. It also lampoons Londoners who invested in the method, being dedicated "to all those double Flats that are not sharp enough to secure their Notes from being transposed into the pockets of an ignorant Pretender."

Things fared better on the continent. Following Louis Spohr's 1820 endorsement of the London "chiroplastic" academy in the Berlin Allgemeine musikalische Zeitung, the Prussian government endorsed the machine in 1821 when funds were created to set up several such academies. A. B. Marx was quick to give a patriotic stamp of approval: "So in Germany [Logier's method] received its scientific acceptance and basis, its general adoption in the science of sound." ${ }^{\prime \prime 1}$ On this basis, Myles Jack-

\footnotetext{
${ }^{89}$ Ibid., 8

${ }^{90}$ Samuel Webbe's academy was located at 20 Bedford Place, Russell Square. See various, An Exposition of the Musical System of Mr Logier, iii.

${ }^{91}$ A. B. Marx, "Zusatz aus andrer Feder," Berliner allgemeine musikalische Zeitung 2 (1825): 58-60, 65-67, 7375 , here 60.
} 


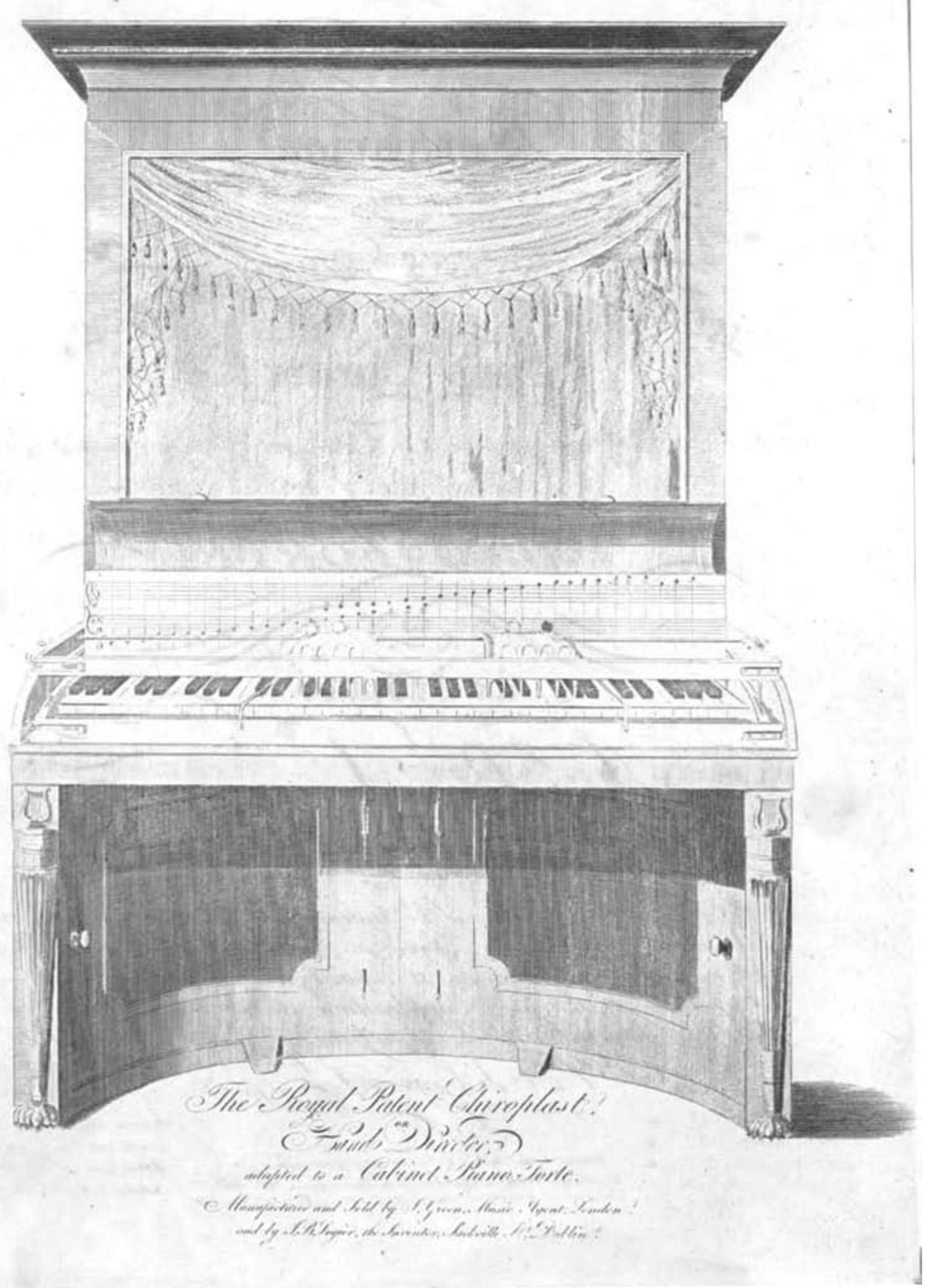

Plate 5: An engraving of J. B. Logier's Chiroplast, given in his First Companion to the Royal Patent Chiroplast (London: I. Green, 1819). Credit: Eda Kuhn Loeb Music Library of the Harvard Library. 

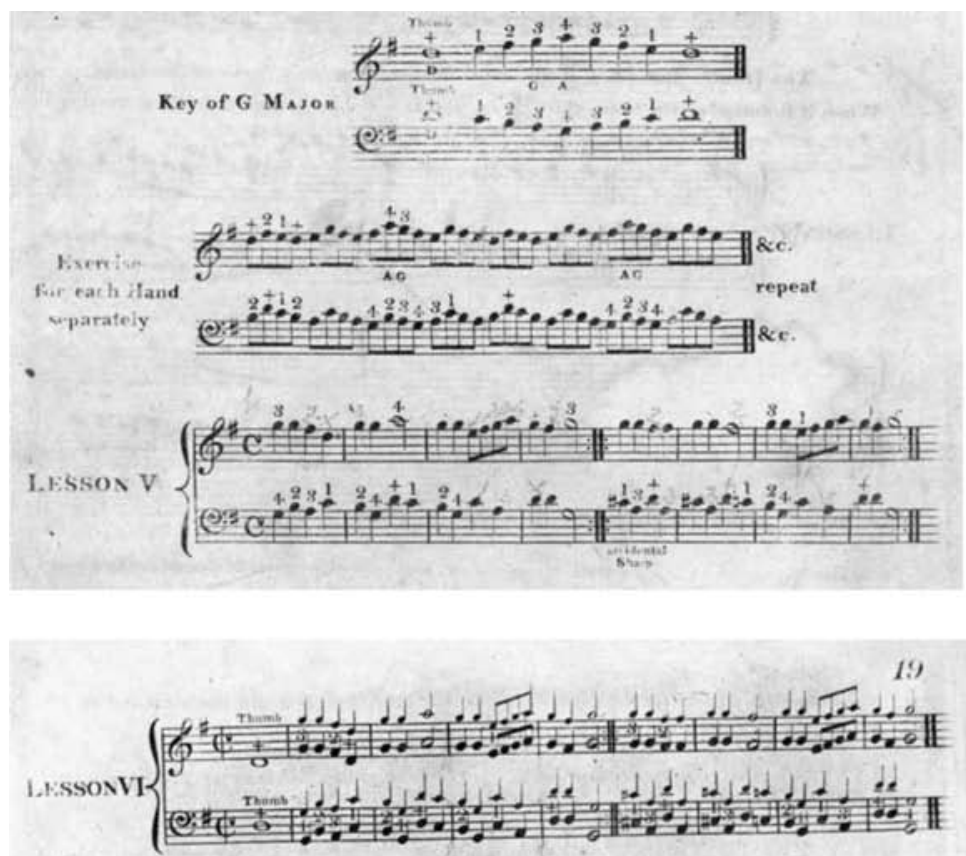

The Double Bar thus, $\|$ divides a Composition into Parts or Sections.

When it is dotted on the Sides thus :\|l: each Part is to be repeated as in the following Lesson.
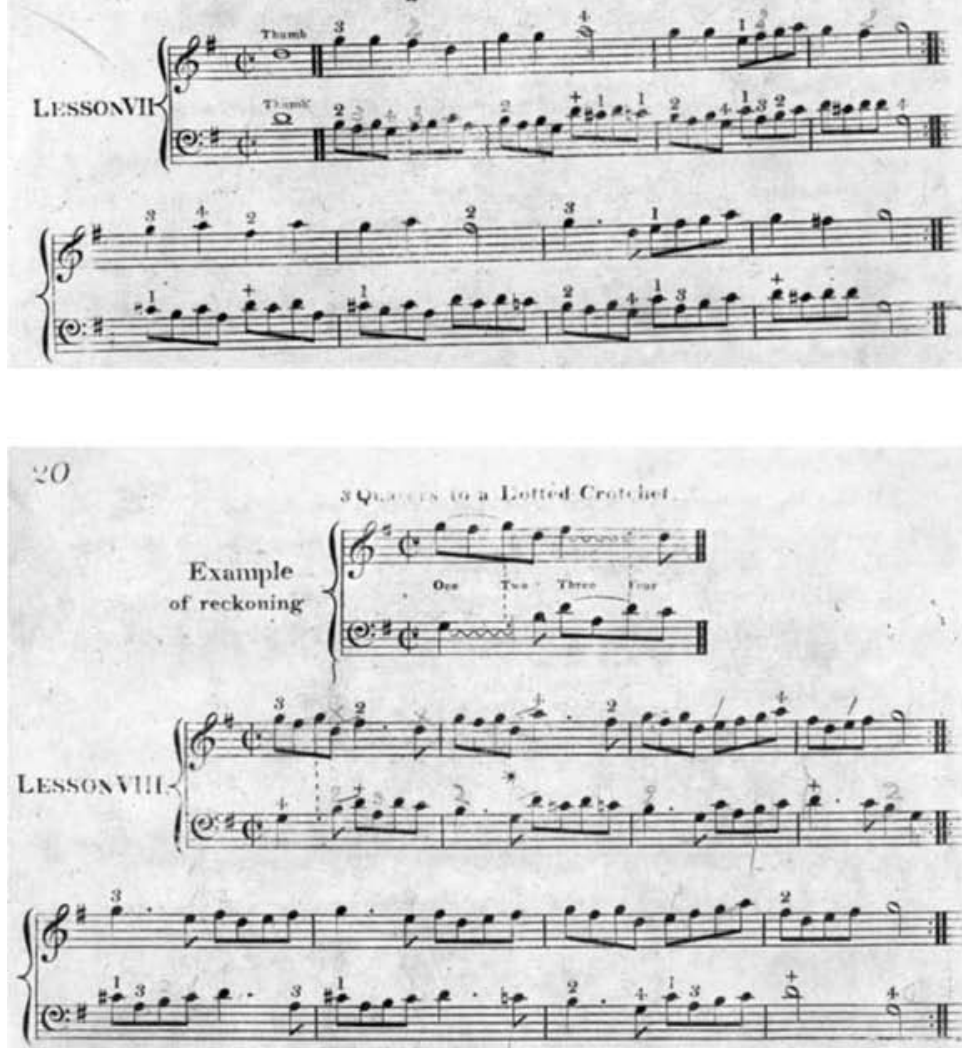

Plate 6: Lessons V-VIII from Logier's First Companion to the Royal Patent Chiroplast (London: I. Green, 1819), 18-20. 


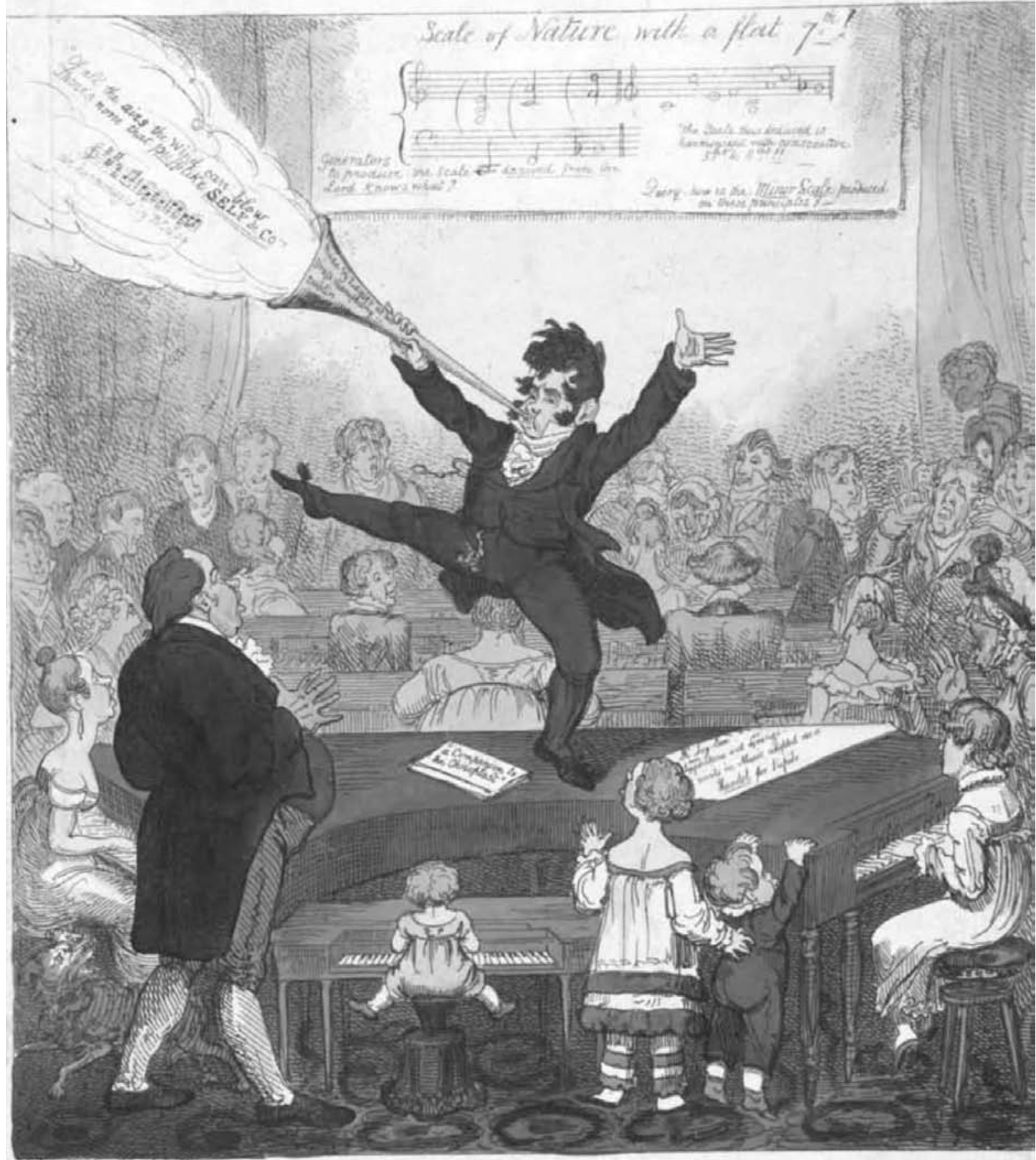

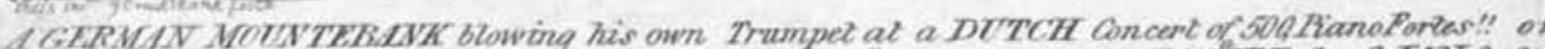

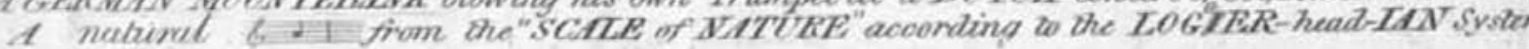

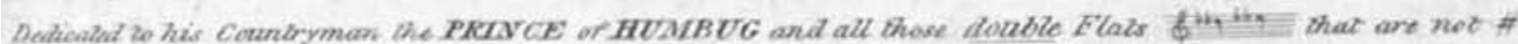

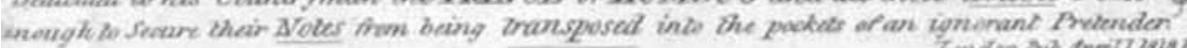

Plate 7: George Cruikshank caricature of Logier, entitled

"A German mountebank blowing his own trumpet at a Dutch concert of 500 piano fortes!!" (1 April 1818). Credit: British Museum 1865, 1111.2093. 
son aptly concludes that "musicians used machines and mechanical principles to teach the skills normally taught by masters, and ... some musicians, rather controversially, saw physicists as possible allies in pedagogical matters." 92 Beyond the executive practices Jackson illuminates, this principle plausibly extends to understandings of compositional pedagogy, as we saw in Czerny's progressive working through musical forms, and Logier's program for collective, virtual labor in harmony and counterpoint.

The broader principle of collective, mechanical exercising of faculties was applied in macrocosm to English education through the socalled monitorial system. Lancaster's Improvements in Education (1803) cites London schools as a social problem for which the solution was a rigorous system of peer monitoring. This principle saw between 200 and 1,000 children sitting in rows in a single room; an adult schoolmaster teaches the monitors (prefects), each of whom relays the lesson mechanically to his or her row, pupil by pupil, like a marble setting other marbles in motion, one by one. Monitors also take attendance, promote pupils, and prepare teaching resources. Discipline was harshly enforced, schools were single-sex, and a guiding principle was that all children must be occupied with tasks at all times to avoid "disgusting scenes of noise and riot." 193 The aspirations behind this mechanical multiplication of learning is illustrated in Lancaster's sample estimate of what his school could achieve and how he would measure it:

Each boy can spell 100 words in a morning: if 100 scholars do this 200 mornings yearly, the following will be the total of their efforts towards improvement:

100 words

200 mornings

20,000 words each boy per ann. 100 boys

$2,000,000$ total words spelt by 100 boys, per ann. The repetition of the same word many times serves to rivet it firmly in the memory, and thus produces

\footnotetext{
${ }^{92}$ Myles W. Jackson, "Physics, Machines and Musical Pedagogy in Nineteenth-Century Germany," History of Science 42 (2004): 371-418, here 374.

${ }^{93}$ Joseph Lancaster, Improvements in Education as it Respects the Industrious Classes of the Community (London: Darton and Harvey, 1803), 7.
}

the total; for the intelligent reader will readily perceive, that the same trouble will occur in teaching 1,000 words distinctly, twenty times over, as would happen in teaching 2,000 distinct words, containing an equal number of syllables, only once over. I have avoided exaggeration in the above statement. ${ }^{94}$

Such quantitative bliss was not widely shared. While cost-efficient nonsectarian education for the working classes formed an important social goal, the Encyclopedia Britannica of 1911 summed up criticism of the monitorial system: as a reduction of the schoolmaster to a bystander; of learning to drill and memorization; and of the curriculum to particles of information and rote sequences. ${ }^{95}$ Perhaps the most critical judgment against the system is not its method but its failure to live up to its promise for efficiency. While figures of high authority may have instilled respectful behavior, contemporary reports to the House of Commons also indicate how discipline could fail. ${ }^{96}$

Reactionary critics voiced concern over the seeming mechanization of education through such systems and devices, as well as the loss of organic life they appeared to represent. Gottfried Weber, for one, was explicitly skeptical of systematic training in music and implicitly attacked Logier's sales pitch to amateurs (that "their more limited object can be attained by $a$ correspondingly shorter route"):

musical art is not susceptible of such a systematic establishment, or at least ... it has thus far failed of proving itself to be so. The little truth which we have as yet discovered in the realm of musical composition, consists merely in a number of experiments

\footnotetext{
${ }^{94}$ Ibid., 59-60.

${ }^{95}$ J. G. F., "Joseph Lancaster," Encyclopaedia Britannica; see https://archive.org/stream/encyclopaediabril6chisrich\# page/148/mode/2up/search/lancaster $\% 2 \mathrm{C}+$ joseph [accessed 16 September 2014].

${ }^{96}$ The following are observations on a girls' monitorial school in Birmingham: "thirty-one girls read Marx xii. to their monitor. The noise in the school was so great that as I sat by the monitor I could not hear the girl who was reading in the class. Several children were laughing to each other, others were inattentive; and the only symptom of reverence in the whole class was, that every time the name of our Lord was pronounced the whole class made a short rapid curtsey. . . . The mistress was occupied in another part of the school." In Minutes of the Committee of Council on Education, 1840-41 (London: William Clowes, 1841), 185.
} 
and observations upon the good or bad effect of this or that combination of tones. But an attempt to derive these facts of experience, in a logically consecutive manner, from any one leading principle and to reduce them to the form of a philosophical science-to a system, has always thus far . . . been destined only to a signal defeat. ${ }^{97}$

In less measured tones, Thomas Carlyle eyed the social effects of such applied learning, famously stating that "not the external and physical alone is now managed by machinery, but the internal and spiritual also. ... We have machines for education: Lancastrian machines; Hamiltonian machines; monitors, maps and emblems." 98 This kind of criticism gave voice to a particular anxiety about the industrial cityscape and increasing mechanization of natural philosophies of mind within Victorian society, what Simon Schaffer has called "the mundane places of intelligence." 99 As plate 8 shows, it too provided a platform for satirists. Caricatures by Robert Seymour, William Heath, Thomas McLean, and others depicted a "march of intellect" in England that was upending society through mass education technologies, ending what Carlyle called "the old natural methods." 100

The implied outcome for music, as depicted here, is to replace casual buskers with a plumed opera diva, a concert harpist, and Vaucanson's mechanical flute player (1737), imagining a shift on London streets from unpretentious popular tunes to composed arias, and from ill-educated, poverty-stricken performers to intricate automata. Even an erstwhile street hustler is envisioned as Wolfgang von Kempelen's "Mechanical Turk" (1770), a world-class chess-playing machine that captivated the European imagination before being revealed as a hoax conceal-

\footnotetext{
${ }^{97}$ Gottfried Weber, An Attempt at a Systematically Arranged Theory of Musical Composition (Boston: Wilkins \& R.B. Carter, 1842), 6.

${ }^{98}$ Thomas Carlyle, "Signs of the Times," The Oxford Book of Essays, ed. John Gross (Oxford: Oxford University Press, 2008), 137 (emphasis added).

${ }^{99}$ Simon Schaffer, "Babbage's Intelligence: Calculating Engines and the Factory System," Critical Inquiry 21 (1994): 203-27, here 204.

${ }^{100}$ Carlyle, "Signs of the Times," 137.
}

ing a human within. ${ }^{101}$ The image registers fear of change: an anxiety toward modern education and technologies of imagined social transformation. Gas street lamps burn anthropomorphically like a small sun, balloon travel dominates the skyline (implicitly replacing sea travel, as ships adopt the technology), steam-powered cars pepper the ground, just as a newspaperreading coach driver and fruit seller learn about the world as a result of the new steam-powered printing press, which brought with it the mass availability of information.

A preexisting continuity is manifest between phrenological principles of exercise-typified in Simpson's law of efficiency common to "the blacksmith's right arm and ... the philosopher's brain" - and the principles of training embodied in Logier's repetitive methods and Czerny's practical school. It makes the case for understanding phrenology as a "manifest discourse" in Foucault's sense: that which is "really no more than the repressive presence of what it does not say." 102 Nauenburg and Berlioz alone among professional musicians made bold statements about phrenology's necessary relation to music (against the anxieties of social change that shadowed it). Far more traceable, for a history written according to documents, is the inexhaustible speech of amateurs who wanted to believe the promise of mechanized mental exercise as a guarantor of self-betterment.

In London, Charles Babbage's principle of automated reason, embodied in the 1822 proposal for a difference engine, is a touchstone in reinforcing the degree to which mental and mechanical interpenetrate: "the analogy between [mechanical] acts and the operations of the mind," he admitted, "almost forced upon me the figurative employment of the same terms. ${ }^{\prime 103}$ Logier's attempt to mechanize piano

\footnotetext{
${ }^{101}$ See Simon Schaffer, "Enlightened Automata," The Sciences in Enlightened Europe, ed. William Clark, Jan Golinski, and Simon Schaffer (Chicago: University of Chicago Press, 1999), 126-65.

${ }^{102}$ Michel Foucault, The Archaeology of Knowledge and the Discourse of Language, trans. A. M. Sheridan Smith (New York: Vintage, 2010), 25.

${ }^{103}$ Charles Babbage, "On the Mathematical Powers of the Calculating Engine," in The Works of Charles Babbage, ed. Martin Campbell-Kelly, 3 vols. (New York: New York University Press, 1989|, III, 31.
} 


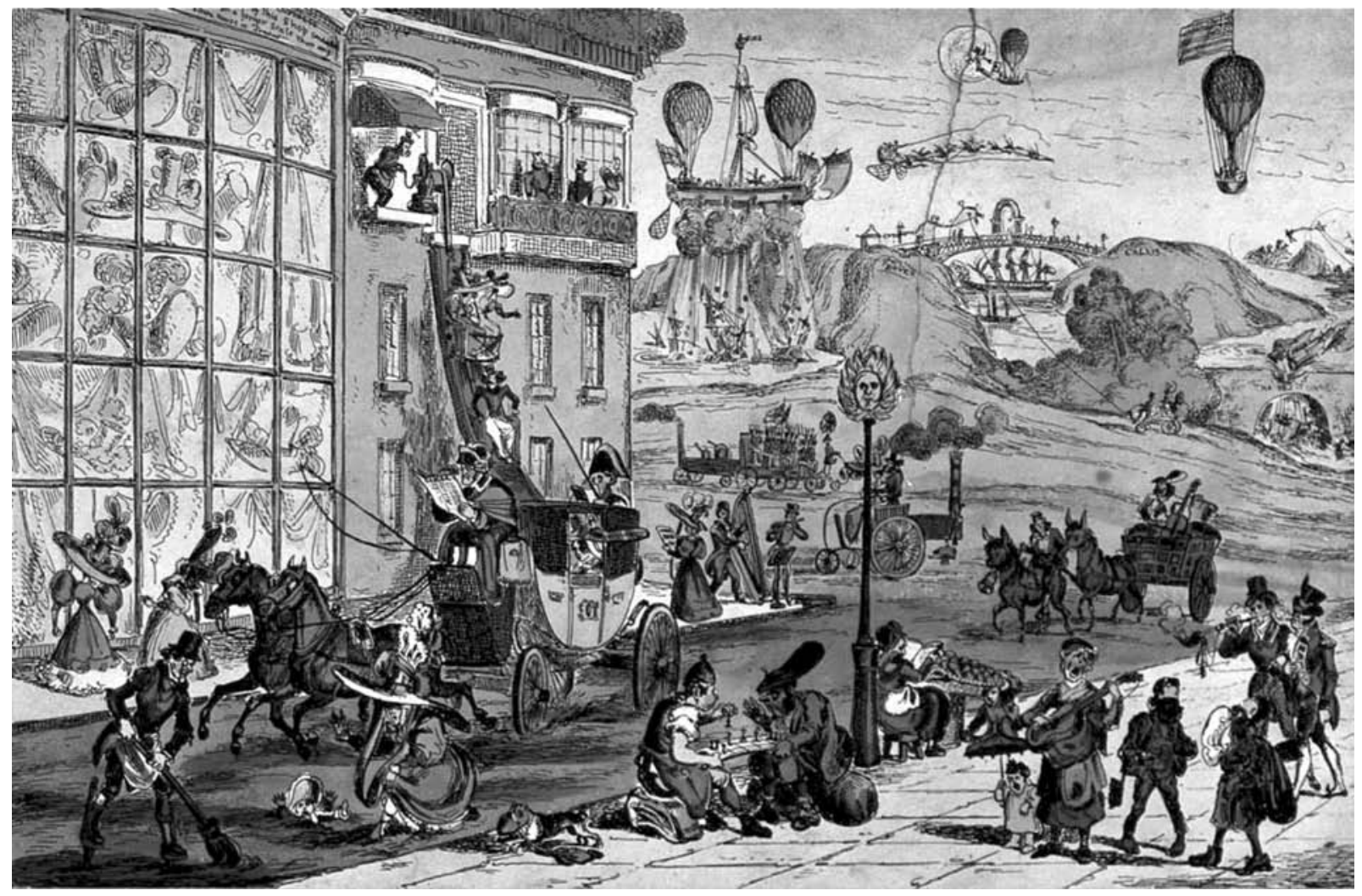

Plate 8: William Heath/ Paul Pry, "A Futuristic Vision: technology is over-sophisticated, and the masses devote themselves to intellectual pursuits, while the basic needs of society are neglected," Color etching, 23 January 1828. Credit: Welcome Library, London.

instruction tapped into the equally mirrored emblems of the piano as a cognitive machine and the mind as a mechanical piano. Later in the century the logician Stanley Jevons (183582) pursued mathematical approaches to economics while at University College London as part of his broader investigation in the laws of thought. Convinced that a system could be automated so that the logical consequences of known states of affairs could be generated efficiently, he was led to the design of a "logical piano . . . capable of replacing for the most part the action of thought required in the performance of logical deduction." ${ }^{\prime 104}$

Herbert Spencer, like Descartes before him, interpreted the brain through the paradigm of

\footnotetext{
${ }^{104}$ Stanley Jevons, "On the Mechanical Performance of Logical Inference," Philosophical Transactions of the Royal Society 160 (1870): 497-518, here 517.
}

the piano on several occasions. ${ }^{105}$ Such a conceit relies on the assumption of the mind's objective presence; in Combe's words, that the "mind in the abstract has no existence." 106 With materialist relish, Spencer would build on the platform set out by Simpson-again, mentioning neither phrenology nor Spurzheim (from whom, indirectly, the principle originates)-to emphasize the necessary physicality of cultivating one's "brain organs" and the social imperative of attending to what he called one's physical conscience: "the fact seems strange that while the raising of first-rate bullocks is

\footnotetext{
${ }^{105}$ Spencer's arguments appear in Principles of Psychology (London: Longman, Brown, Green, and Longmans, 1855). For an overview, see C. U. M. Smith, "Evolution and the Problem of Mind: Part 1," Journal of the History of Biology 15 (1982): $55-88$.

${ }^{106}$ Combe, A System of Phrenology, 5th edn., 2 vols. (London: Longman, 1843), II, 407.
} 
an occupation on which educated men willingly bestow much time and thought, the bringing up of fine human beings is an occupation tacitly unworthy of their attention." $\mathrm{He}$ quipped, "we see infinite pains taken to produce a racer that shall win the Derby: none to produce a modern athlete"; or a modern musician, we might add (holding in abeyance the above reading of Czerny and Logier). ${ }^{107}$

Ultimately, the emphasis on materialism in the service of artistic education marks an attitude that saw the basic divide weaken between an aesthetics of metaphysical prime causes and one of empirical, progressive science. While such a rapprochement was not uncontested in the mid-nineteenth century, it speaks to an age quite different from C. P. Snow's "two cultures" a century later, whose tacit call for unification was famously eviscerated by F. R. Leavis as "portentously ignorant. . . . [Snow] is intellectually as undistinguished as it is possible to be." 108 However distorting it proved, the perspective of phrenology subsumed this caustic divide. And however casuistic its reasoning, and deceptive its demonstrations, its discourse highlights a widespread belief in the methodical means of cultivating intellectual skill, which must include musical skill. Such a belief is summarized in Spurzheim's assertion that human nature "is susceptible of perfection or degradation," a condition that justified for him monitorial education as principally a system of "continued exercise."109 The extent to which figures like Logier, Czerny, and Weber understood composition and performance as perfect-

${ }^{107}$ Herbert Spencer, Education: Intellectual, Moral, and Physical (London: G. Manwaring, 1861), 146.

${ }^{108}$ F. R. Leavis, Two Cultures? The Significance of C. P. Snow (Cambridge: Cambridge University Press, 2013), 5354.

${ }^{109}$ Spurzheim, A View of the Elementary Principles of Education, 2, 136. ible activities in this sense remains an open question. To return one last time to Nauenburg: "Since we troubled ourselves to lower our art to physiological and psychological foundations," he demurs, "it entered into the ranks of the modern perfectible sciences." 110 With such strained irony, few statements could better summarize the ambivalence of music's status in an age of phrenological science.

\begin{abstract}
110"Seitdem wir unsere Kunst auf physiologische und psychologische Basis zu reduciren bemüht sind, tritt sie in die Reihe der modernen Perkectibilitätswissenschaften." Nauenburg, "Die Phrenologie in ihrer Beziehung zur Tonkunst," Neue Zeitschrift für Musik 2 (1851): 13 (emphasis added).
\end{abstract}

\section{Abstract.}

The icon of the machine in early-nineteenth-century Britain was subject to a number of contemporary critiques in which pedagogy and the life of the mind were implicated, but to what extent was education in music composition influenced by this? A number of journal articles appeared on the topic of music and phrenology, bolstered by the establishment of the London Phrenological Society (1823), and its sister organization, the British Phrenological Association (1838). They placed the creative imagination, music, and the "natural" life of the mind into a fraught discourse around music and materialism. The cost of a material mind was a perceived loss of contact with the "gifts of naturer . . the dynamical nature of man ... the mystic depths of man's soul" (Carlyle), but the concept of machine was also invested with magical potential to transform matter, to generate energy, and can be understood as a new ideal type of mechanism. These confliciting ideals and anxieties over mechanism, as paradigm and rallying cry, are here situated in the context of music pedagogy during the second quarter of the century, with particular reference to amateur musicians and the popular appeal of phrenological "exercise," and of devices such as Johann Bernhard Logier's "chiroplast." Keywords: phrenology, chiroplast, Johann Bernhard Logier, materialism, machine, music pedagogy 